\title{
Single-particle characterization of aerosols collected at a remote site in the Amazonian rainforest and an urban site in Manaus, Brazil
}

\author{
Li Wu ${ }^{1}$, Xue Li ${ }^{1}$, HyeKyeong Kim ${ }^{1}$, Hong Geng $^{2}$, Ricardo H. M. Godoi ${ }^{3}$, Cybelli G. G. Barbosa ${ }^{3}$, Ana F. L. Godoi ${ }^{3}$, \\ Carlos I. Yamamoto ${ }^{4}$, Rodrigo A. F. de Souza ${ }^{5}$, Christopher Pöhlker ${ }^{6}$, Meinrat O. Andreae ${ }^{6,7}$, and Chul-Un Ro ${ }^{1}$ \\ ${ }^{1}$ Department of Chemistry, Inha University, Incheon, 402-751, Republic of Korea \\ ${ }^{2}$ Institute of Environmental Science, Shanxi University, Taiyuan 030006, China \\ ${ }^{3}$ Environmental Engineering Department, Federal University of Paraná - UFPR, Curitiba, Paraná, Brazil \\ ${ }^{4}$ Chemical Engineering Department, Federal University of Paraná - UFPR, Curitiba, Paraná, Brazil \\ ${ }^{5}$ Amazonas State University, Superior School of Technology, Manaus, Amazonas, Brazil \\ ${ }^{6}$ Multiphase Chemistry and Biogeochemistry Departments, Max Planck Institute for Chemistry, 55020 Mainz, Germany \\ ${ }^{7}$ Department of Geology and Geophysics, King Saud University, Riyadh, Saudi Arabia
}

Correspondence: Chul-Un Ro (curo@inha.ac.kr)

Received: 6 October 2018 - Discussion started: 15 October 2018

Revised: 18 January 2019 - Accepted: 24 January 2019 - Published: 31 January 2019

\begin{abstract}
In this study, aerosol samples collected at a remote site in the Amazonian rainforest and an urban site in Manaus, Brazil, were investigated on a single-particle basis using a quantitative energy-dispersive electron probe X-ray microanalysis (ED-EPMA). A total of 23 aerosol samples were collected in four size ranges $(0.25-0.5,0.5-1.0,1.0-$ 2.0, and 2.0-4.0 $\mu \mathrm{m}$ ) during the wet season in 2012 at two Amazon basin sites: 10 samples in Manaus, an urban area; and 13 samples at an $80 \mathrm{~m}$ high tower, located at the Amazon Tall Tower Observatory (ATTO) site in the middle of the rainforest, $150 \mathrm{~km}$ northeast of Manaus. The aerosol particles were classified into nine particle types based on the morphology on the secondary electron images (SEIs) together with the elemental concentrations of 3162 individual particles: (i) secondary organic aerosols (SOA); (ii) ammonium sulfate (AS); (iii) SOA and AS mixtures; (iv) aged mineral dust; (v) reacted sea salts; (vi) primary biological aerosol (PBA); (vii) carbon-rich or elemental carbon (EC) particles, such as soot, tarball, and char; (viii) fly ash; and (ix) heavy metal ( $\mathrm{HM}$, such as $\mathrm{Fe}, \mathrm{Zn}, \mathrm{Ni}$, and $\mathrm{Ti}$ )-containing particles. In submicron aerosols collected at the ATTO site, SOA and AS mixture particles were predominant (50\%-94\% in relative abundance) with SOA and ammonium sulfate comprising $73 \%-100 \%$. In supermicron aerosols at the ATTO site, aged mineral dust and sea salts $(37 \%-70 \%)$ as well as SOA and ammonium sulfate $(28 \%-58 \%)$ were abundant. PBAs
\end{abstract}

were observed abundantly in the $\mathrm{PM}_{2-4}$ fraction (46\%), and EC and fly ash particles were absent in all size fractions. The analysis of a bulk $\mathrm{PM}_{0.25-0.5}$ aerosol sample from the ATTO site using Raman microspectrometry and attenuated total reflection Fourier-transform infrared spectroscopy (ATR-FTIR) showed that ammonium sulfate, organics, and minerals are the major chemical species, which is consistent with the ED-EPMA results. In the submicron aerosols collected in Manaus, either SOA and ammonium sulfate $(17 \%$ $80 \%$ ) or EC particles $(6 \%-78 \%)$ were dominant depending on the samples. In contrast, aged mineral dust, reacted sea salt, PBA, SOA, ammonium sulfate, and EC particles comprised most of the supermicron aerosols collected in Manaus. The SOA, ammonium sulfate, and PBAs were mostly of a biogenic origin from the rainforest, whereas the EC and HM-containing particles were of an anthropogenic origin. Based on the different contents of SOA, ammonium sulfate, and EC particles among the samples collected in Manaus, a considerable influence of the rainforest over the city was observed. Aged mineral dust and reacted sea-salt particles, including mineral dust mixed with sea salts probably during long-range transatlantic transport, were abundant in the supermicron fractions at both sites. Among the aged mineral dust and reacted sea-salt particles, sulfate-containing ones outnumbered those containing nitrates and sulfate + nitrate in the ATTO samples. In contrast, particles containing sul- 
fate + nitrate were comparable in number to particles containing sulfate only in the Manaus samples, indicating the different sources and formation mechanisms of secondary aerosols, i.e., the predominant presence of sulfate at the ATTO site from mostly biogenic emissions and the elevated influences of nitrates from anthropogenic activities at the Manaus site.

\section{Introduction}

The Amazonian rainforest is regarded as one of the primitive continental regions and atmospheric aerosol particles over the region are expected to be influenced minimally by anthropogenic activities, particularly during the wet season (Andreae, 2007; Martin et al., 2010b; Chen et al., 2015). The unique near-natural conditions during the wet season make it an ideal place to understand the occurrence, nature, origin, and transport of aerosol particles, which can directly scatter and absorb solar radiation and indirectly serve as cloud condensation nuclei $(\mathrm{CCN})$ and/or ice nuclei (IN), to better predict the additional anthropogenic effects on aerosol particles, and to help determine their influences on the environment, climate, and human health (Artaxo et al., 2013). The Amazon Tall Tower Observatory (ATTO) consists of several observatory towers built in the middle of the Amazon rainforest for a continuous and detailed study of biota-atmosphere interactions (Andreae et al., 2015). Manaus, the capital of the Amazonas State, is a large city located in the northern region of Brazil with more than 2 million inhabitants in an area of $11401 \mathrm{~km}^{2}$ (IBGE, 2017). The city, which is surrounded by the largest tropical rainforest, has a large industrial zone; a port area at the Rio Negro; an energy matrix based on fuel oil, diesel, and natural gas; and a growing automotive fleet (Martin et al., 2010a, 2016). Consequently, the pollution plume from Manaus can act as a laboratory for examining the perturbations in natural processes (Martin et al., 2016). Only a few studies examined airborne particles over the Amazon rainforest and nearby urban sites simultaneously (Fraund et al., 2017; Martin et al., 2016). Therefore, there is still little information on the urban vs. ecosystem influences. Especially, single-particle characterization of aerosols collected at a Manaus city center has been scarce.

Many studies have been performed on the aerosol characteristics in the Amazon basin, but the formation and dynamic processes of Amazonian aerosols are not completely understood (Andreae et al., 2015; Martin et al., 2010a, 2016; Fraund et al., 2017; Fan et al., 2018). The Amazon basin atmosphere is near-pristine during the wet season, whereas biomass burning prevails during the dry season (Andreae, 2007; Pöschl et al., 2010; Artaxo et al., 2013; Pöhlker et al., 2018). Based on a long-term study, it was reported that aerosol particles in the coarse fraction are relatively constant in concentrations through the wet and dry sea- sons, whereas the aerosol particle levels in the fine fraction differ due to the predominant influence of biomass burning during the dry season (Artaxo et al., 2013; MoranZuloaga et al., 2018). Scanning electron microscopy-energydispersive X-ray spectrometry (SEM/EDX) studies categorized the Amazonian aerosols mainly as secondary organic aerosol (SOA) particles, sulfates and/or chlorides, primary biological aerosol (PBA) particles, mineral dust, sea salts (fresh and/or aged), and pyrogenic carbon particles within the different size fractions (Krejci et al., 2005; Pöschl et al., 2010). Over the Amazonian rainforest, SOA particles are mainly formed through the condensation of biogenic organic compounds onto biogenic K-rich salt particles emitted from the forest and are predominant in the fine fraction, which is important for CCN (Pöhlker et al., 2012) and can also affect the potential of mineral particles when acting as an organic coating (Möhler et al., 2008). Under high-relative-humidity conditions, nano- and micrometer SOA particles with a dominance of $\alpha$-pinene and isoprene as their precursors can remain in the liquid phase (Bateman et al., 2016), which further enhances the formation of SOA as well as the oxygento-carbon $(\mathrm{O} / \mathrm{C})$ ratios. Hence, the study of this particle type can help elucidate some of the atmospheric interactions (Lin et al., 2014). The atmosphere in the Amazon basin is also rich in PBA particles (Andreae, 2007; Artaxo et al., 1998, 2013; Martin et al., 2010a). Their unique morphology and elemental compositions of major $\mathrm{C}$ and $\mathrm{O}$ with minor $\mathrm{S}, \mathrm{K}$, $\mathrm{P}, \mathrm{Na}, \mathrm{N}, \mathrm{Cl}$, and/or $\mathrm{Mg}$ obtained by SEM/EDX are characteristic of individual PBAs like fungal spores (China et al., 2016). PBA particles can contribute to $\mathrm{CCN}$ after being transported to cloud formation altitudes by strong convection (Artaxo et al., 2013). At the ATTO site, single-particle analysis by a combination of scanning transmission X-ray microscopy and near edge X-ray absorption fine structure spectroscopy (STXM/NEXAFS) and SEM/EDX highlighted the dominance of biological particles, and the abundance of biogenic SOA and the presence of $\mathrm{C}, \mathrm{N}, \mathrm{O}, \mathrm{P}$, and $\mathrm{K}$ are characteristic of aerosols at the area (Fraund et al., 2017). Based on an investigation on particulate matter (PM) during the wet season, oxidized organic components were significantly observed at Manaus sites (de Sá et al., 2018), where one-third of the potential SOA would be of an urban origin (Palm et al., 2018).

In this study, 23 aerosol samples collected at the ATTO site and at an urban site in Manaus during the wet season in 2012 were examined on a single-particle basis using a quantitative energy-dispersive electron probe X-ray microanalysis (EDEPMA), which provided information on the morphology and chemical compositions of aerosols containing both light and heavy elements. This paper presents the different characteristics of the aerosols collected at the rainforest and in Manaus. 


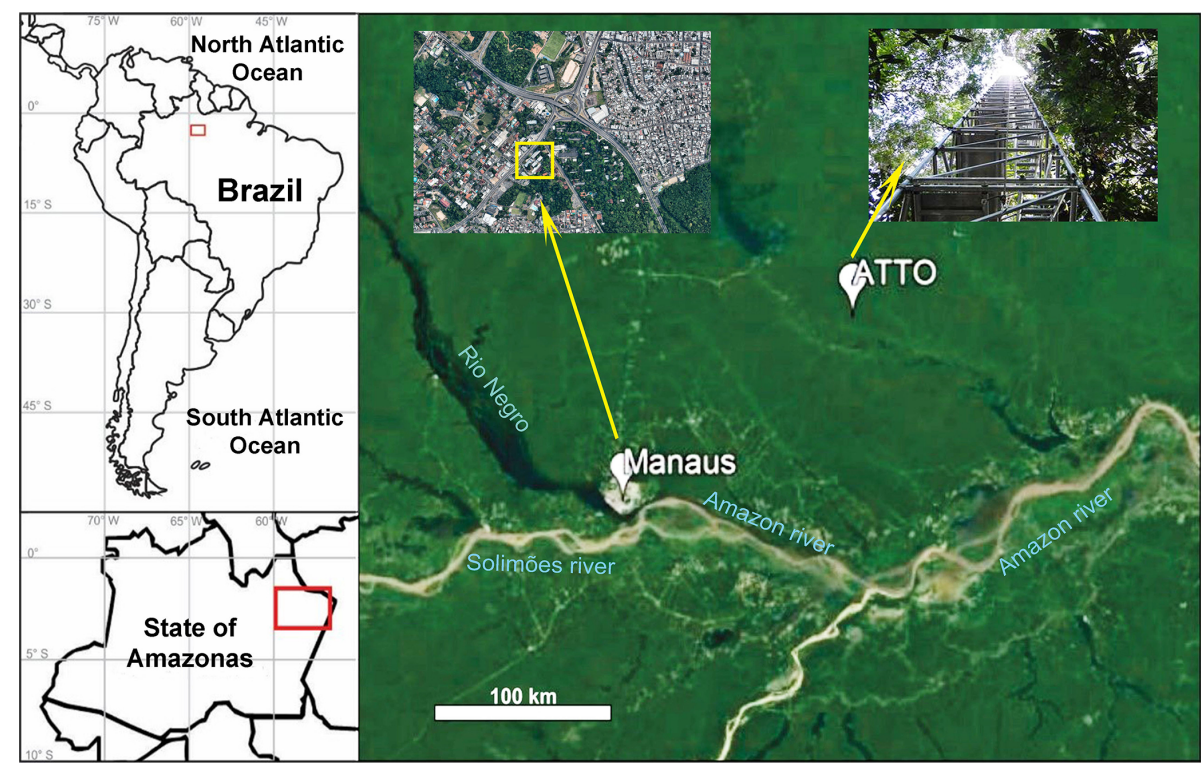

Figure 1. Location of sampling sites at the Brazilian Amazon basin: an urban site in Manaus ( $\left.3^{\circ} 05.753^{\prime} \mathrm{S}, 59^{\circ} 59.419^{\prime} \mathrm{W}\right)$ and a rainforest site at ATTO $\left(02^{\circ} 647^{\prime} \mathrm{S}, 58^{\circ} 59.992^{\prime} \mathrm{W}\right)$. Map of South America (top left panel) with the region marked with a red rectangle and a map of the Amazonas State, Brazil (bottom left panel), also with the region of interest marked in red.

\section{Experimental section}

\subsection{Samples}

During the wet season in 2012, aerosol samples were collected at two sampling sites on the Amazon basin, i.e., ATTO and a central area of Manaus. The ATTO site $\left(02^{\circ} 08.647^{\prime} \mathrm{S}\right.$, $58^{\circ} 59.992^{\prime} \mathrm{W}$ ) is situated in the Uatumã Sustainable Development Reserve, approximately $150 \mathrm{~km}$ northeast of Manaus (Fig. 1). This is a multidisciplinary research site of an international joint project between Brazil and Germany for continuous monitoring of the biological, physical, and chemical functions of the Amazon rainforest to answer questions related to climate change (Andreae et al., 2015). Aerosol sampling was performed at an $80 \mathrm{~m}$ height walk-up tower at the ATTO site. In Manaus, the sampling site is situated in the central part of the city $\left(03^{\circ} 05.753^{\prime} \mathrm{S}, 59^{\circ} 59.419^{\prime} \mathrm{W}\right)$, which is at a representative urban region influenced by electricity production based on fuel oil, diesel, and natural gas; biogenic emissions from the surrounding forest; and mostly by light-duty (using gasoline and ethanol) vehicle traffic. Heavy vehicles that use diesel amount to less than $10 \%$ of the urban fleet (Medeiros et al., 2017). The location is nearby a small parking area and around $200 \mathrm{~m}$ away from the intersection of four busy avenues, with frequent diurnal traffic jam on weekdays. Particles were collected at a $2 \mathrm{~m}$ height above ground level. The aerosol samples were collected on TEM (transmission electron microscopy) grids (Ted Pella Inc., USA, formvar/carbon 200 mesh $\mathrm{Cu}$ grid, 35-70 nm thickness) using a five-stage Battelle impactor (the cutoff diameters are $0.25,0.5,1,2$, and $4 \mu \mathrm{m}$ for stages $1-5$, re- spectively) at the ATTO and Manaus sites on 1, 16, 17, and 18 April and 1-3 May (the 4- and 3-day samples were collected at the ATTO and Manaus sites, which are notated as samples SA1-SA4 and SM1-SM3, respectively). On each date, the sampling started around noon (local time) and lasted for approximately $100 \mathrm{~min}$. The individual particles collected on stages 1-3 $\left(\mathrm{PM}_{0.25-0.5}, \mathrm{PM}_{0.5-1.0}\right.$, and $\left.\mathrm{PM}_{1.0-2.0}\right)$ for each sample and on an additional stage $4\left(\mathrm{PM}_{2.0-4.0}\right)$ for the SA4 and SM3 samples were examined.

During the sampling period, the temperature was in the range of 22 to $32{ }^{\circ} \mathrm{C}$ and the relative humidity (RH) was above $55 \%$. On 16 April and 1 and 2 May, rain events occurred within the previous $24 \mathrm{~h}$ prior to sampling. Detailed information on sampling dates and times and the meteorological conditions during the samplings are given in Table 1. The 10-day backward air-mass trajectories were obtained using the Hybrid Single-Particle Lagrangian Integrated Trajectory (HYSPLIT) model from the NOAA Air Resources Laboratory's web server (http://www.arl. noaa.gov/ready/hysplit4.html), as shown in Fig. 2. In the HYSPLIT calculation, meteorological data output from the Global Data Assimilation System (GDAS) using GDAS1 data with a horizontal resolution of $1^{\circ}$ corresponding to $\sim 100 \mathrm{~km} \times 100 \mathrm{~km}$ and 23 vertical layers was used, which was reported to provide plausible backward trajectory analysis (Su et al., 2015). All samples were influenced by transatlantic air masses at a $1000 \mathrm{~m}$ receptor height and the Manaus site was influenced mainly by the surrounding rainforest at 500 and $100 \mathrm{~m}$ heights. 
Table 1. Sampling dates, sampling times, and metrological conditions during the samplings.

\begin{tabular}{|c|c|c|c|c|c|c|c|}
\hline $\begin{array}{l}\text { Sampling } \\
\text { site }\end{array}$ & Sample & $\begin{array}{l}\text { Sampling } \\
\text { date }\end{array}$ & $\begin{array}{l}\text { Sampling } \\
\text { time }\end{array}$ & $\begin{array}{c}T \\
\left({ }^{\circ} \mathrm{C}\right)\end{array}$ & $\begin{array}{l}\mathrm{RH} \\
(\%)\end{array}$ & $\begin{array}{c}\text { Rainfall } \\
(\mathrm{mm})\end{array}$ & Sampling conditions \\
\hline \multirow{4}{*}{ ATTO } & SA1 & 1 April 2012 & $12: 25-14: 25$ & 28 & 72 & 9 & \multirow{4}{*}{$\begin{array}{l}\text { Precipitation during the TEM grid exposure } \\
\text { Precipitation }(1 \mathrm{~mm}) \text { in the last } 24 \mathrm{~h} \text { before } \\
\text { the TEM grid exposure } \\
\text { No precipitation } \\
\text { No precipitation }\end{array}$} \\
\hline & SA2 & 16 April 2012 & $12: 12-13: 52$ & 28 & 74 & 0 & \\
\hline & SA3 & 17 April 2012 & $12: 13-13: 53$ & 30 & 60 & 0 & \\
\hline & SA4 & 18 April 2012 & 12:04-13:45 & 27 & 75 & 0 & \\
\hline \multirow{3}{*}{ Manaus } & SM1 & 1 May 2012 & $12: 17-13: 57$ & 32 & 57 & 0 & $\begin{array}{l}\text { Precipitation }(1 \mathrm{~mm}) \text { in the last } 24 \mathrm{~h} \text { before } \\
\text { the TEM grid exposure }\end{array}$ \\
\hline & SM2 & 2 May 2012 & $12: 00-13: 40$ & 27 & 73 & 0 & $\begin{array}{l}\text { Precipitation }(2 \mathrm{~mm}) \text { in the last } 24 \mathrm{~h} \text { before } \\
\text { the TEM grid exposure }\end{array}$ \\
\hline & SM3 & 3 May 2012 & $12: 06-13: 46$ & 24 & 88 & 8 & Precipitation during the TEM grid exposure \\
\hline
\end{tabular}
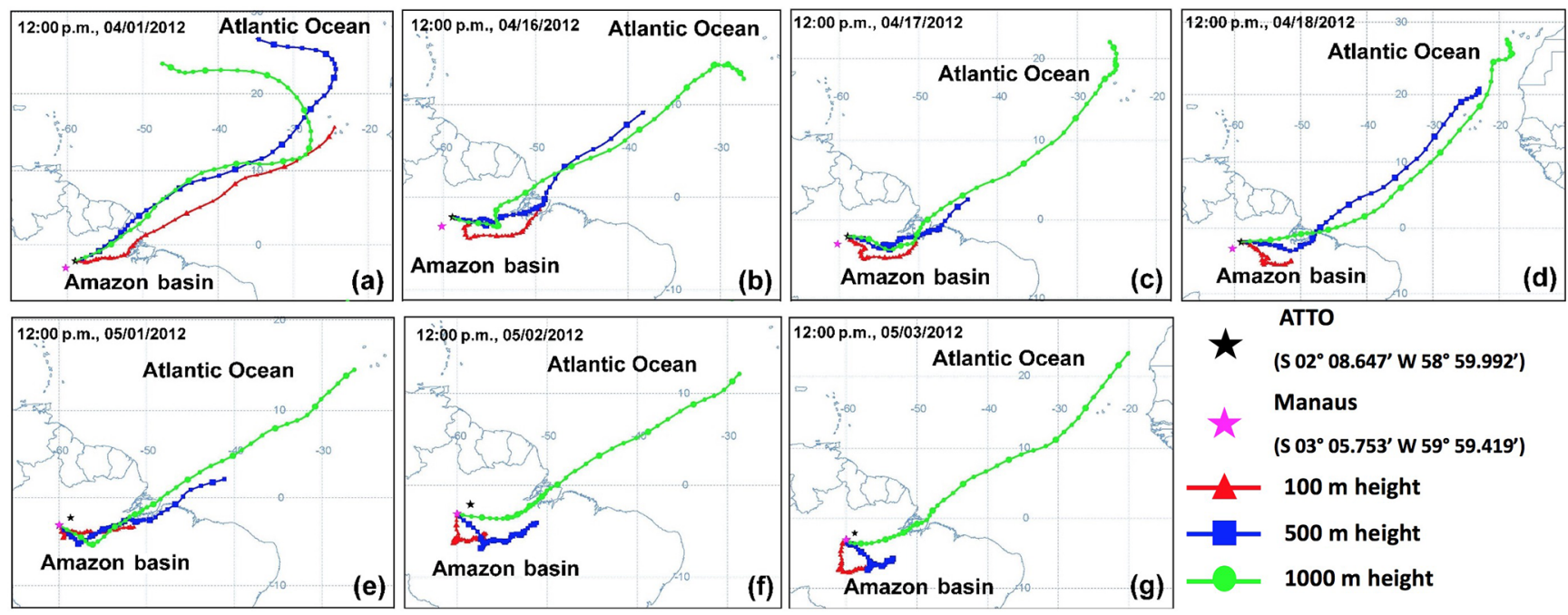

ATTO

Figure 2. The 10-day $(240 \mathrm{~h})$ backward air-mass trajectories at 100, 500, and $1000 \mathrm{~m}$ receptor heights (a-d) for the SA1-SA4 samples collected on 1 and 16-18 April 2012 at the ATTO site and (e-g) for the SM1-SM3 samples collected on 1-3 May 2012 at the Manaus site. The Hybrid Single-Particle Lagrangian Integrated Trajectory (HYSPLIT) model available at the NOAA Air Resources Laboratory's web server (http://www.arl.noaa.gov/ready/hysplit4.html, last access: 30 January 2019) was used.

\subsection{EPMA measurements and data analysis}

Low- $Z$ particle EPMA was carried out by SEM (JSM-6390, JEOL) equipped with an Oxford Link SATW ultrathin window EDX detector, which has a spectral resolution of $133 \mathrm{eV}$ for Mn $K_{\alpha} \mathrm{X}$-rays. The X-ray spectra were recorded using INCA Energy software. To achieve the optimal experimental conditions, such as the low background level in the $\mathrm{X}$ ray spectra and good sensitivity for low- $Z$ element analysis, an accelerating voltage of $10 \mathrm{kV}$, a beam current of $0.5 \mathrm{nA}$, and a measuring time of $20 \mathrm{~s}$ were used. X-ray spectral data acquisition for individual particles was carried out manually in point analysis mode; i.e., the electron beam was focused at the center of each particle, and X-rays were acquired while the beam remained fixed on this single spot. The secondary electron images (SEIs) and X-ray spectra of an over- all 3162 individual particles for the ATTO and Manaus samples were examined. As the TEM grids are thin $(35-70 \mathrm{~nm}$ thickness), strong $\mathrm{X}$-rays from the $\mathrm{Al}$ or $\mathrm{Cu}$ metal stub commonly used in the SEM/EDX measurement would be a problem when the TEM grid substrate is placed on it. A homemade sample holder (Fig. 3a) for the TEM grid samples was used to avoid interference from the metal stub, resulting in $\mathrm{X}$-ray spectra of bare TEM grids, which showed only $\mathrm{C}$ and $\mathrm{O} X$-ray peaks from their formvar/carbon thin film, a $\mathrm{Cu}-\mathrm{L}$ peak caused by lateral scattering from the $\mathrm{Cu}$ bars of TEM grids, and a Si peak from an impurity, as shown in Fig. $3 b$. The net X-ray intensities for the chemical elements were obtained by nonlinear, least-squares fitting of the spectra using the AXIL program (Vekemans et al., 1994). Although the characteristic X-ray intensities of $\mathrm{C}$ and $\mathrm{O}$ were low for the bare TEM grids, determination of the $\mathrm{C}$ and $\mathrm{O}$ concen- 
(a) TEM grids holder

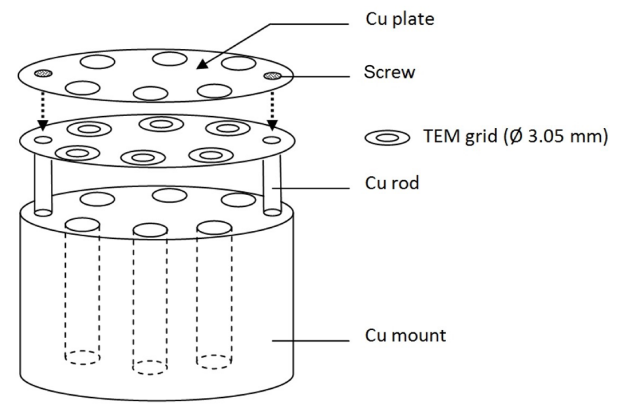

(b) X-ray spectrum of TEM grids

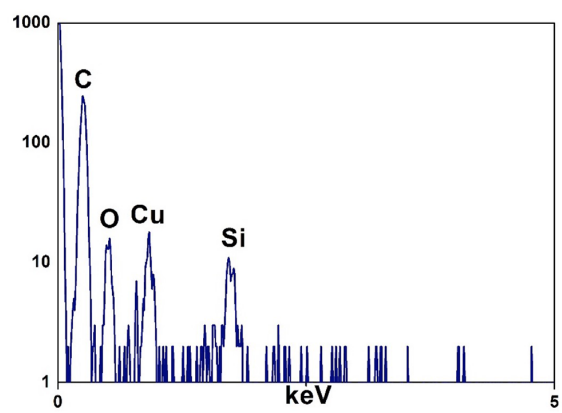

Figure 3. Homemade sample holder for TEM grid samples in SEM/EDX measurements and a typical X-ray spectrum of the TEM grids.

trations for individual particles on the TEM grids was performed using a methodology based on the Monte Carlo calculation technique to correct for the interfering X-ray peaks of $\mathrm{C}$ and $\mathrm{O}$ emitted from the TEM grid, which provided reliable quantification results when applied to the quantification of standard (sub)micron particles, such as $\mathrm{CaCO}_{3}$, $\mathrm{CaSO}_{4}, \mathrm{Na}_{2} \mathrm{SO}_{4}$, and $\mathrm{SiO}_{2}$. On the other hand, electronbeam-sensitive particles, such as $\mathrm{NaNO}_{3}, \mathrm{Ca}\left(\mathrm{NO}_{3}\right)_{2} \cdot 4 \mathrm{H}_{2} \mathrm{O}$, and ammonium sulfate, provided deviating quantification results (Geng et al., 2010). As the $\mathrm{Cu}-\mathrm{L}$ and Si X-ray intensities from the bare TEM grids are quite small $(<20$ counts per second) under these measurement conditions, the two peaks could be neglected safely during the quantification procedure.

\section{Results and discussion}

\subsection{Particle types observed in samples collected at the ATTO and Manaus sites}

In this study, the analyzed particles were classified based on their X-ray spectral and SEI data, where nine different particle types were observed in the samples collected at the ATTO and Manaus sites during the wet season in 2012: i.e., (i) SOA; (ii) ammonium sulfate (AS) particles; (iii) SOA and AS mixture particles; (iv) aged (reacted) sea salt; (v) aged mineral dust; (vi) PBA particles; (vii) carbon-rich or elemental carbon (EC) particles such as soot, tarball, and char or coal dust; (viii) fly ash particles; and (ix) heavy-metal-containing (HM) particles. In a previous study (Pöschl et al., 2010), five types of aerosols, such as (i) SOA droplets, (ii) SOA-inorganic mixture particles where the inorganics are mostly sulfates and/or chlorides, (iii) PBA, (iv) mineral dust, and (v) pyrogenic carbon particles, were reported based on single-particle analysis for aerosol samples collected at a remote site north of Manaus, Brazil, during the 2008 wet season (3-13 March) using SEM/EDX. The pure SOA droplets dominated in the nucleation and Aitken modes, whereas the pure SOA, SOAinorganic mixture particles, and pyrogenic carbon particles dominated in accumulation mode (Pöschl, et al., 2010). With the exception of the reacted sea-salt particles probably from the Atlantic Ocean as well as the abundant ammonium sulfate aerosols, the particle types observed in this study are comparable to their study. Figures 4 and 5 present typical field SEIs for submicron and supermicron aerosol particles collected at the ATTO and Manaus sites, respectively, where the chemical species comprising each particle is indicated. Ammonium sulfate and SOA particles are dominant in the sub- and supermicron aerosol fractions collected at the ATTO site with some mineral particles and aged sea salts in the supermicron fractions, whereas the aerosol samples collected at the Manaus site are composed of various types of particles of anthropogenic and/or natural origin. Figures S1-S7 in the Supplement present typical SEIs for all the samples with identified chemical species on the SEIs, which helps briefly illustrate the different features of the samples collected at the ATTO and Manaus sites. The characteristics of the particle types observed in the ATTO and Manaus samples are described in the following.

\subsubsection{Secondary organic aerosol (SOA) particles}

In this study, SOA particles were observed frequently in both the ATTO and Manaus samples, even though pure SOA particles were rare and most of them were mixed internally with other species, such as ammonium sulfate, K-rich salt, and reacted sea salts. The SOA particles over the Amazon rainforest are formed by the oxidation of biogenic volatile organic compounds (Jimenez et al., 2009; Hallquist et al., 2009; Martin et al., 2010a; Andreae et al., 2018) and are the major constituents of particulate matter, particularly for submicron ambient PM (Pöschl et al., 2010; Martin et al., 2010b; Chen et al., 2015). In the SEI images, pure SOA droplet particles appear gray in contrast and have a circular shape, as shown in Fig. 6a. As TEM grid films (with $90 \%$ $\mathrm{C}$ content) and SOAs are composed mainly of carbon and oxygen, the SOA aerosols appear gray on the TEM grids because of their similar secondary and backscattered electron yields to those of the TEM grid (Goldstein et al., 2003; 

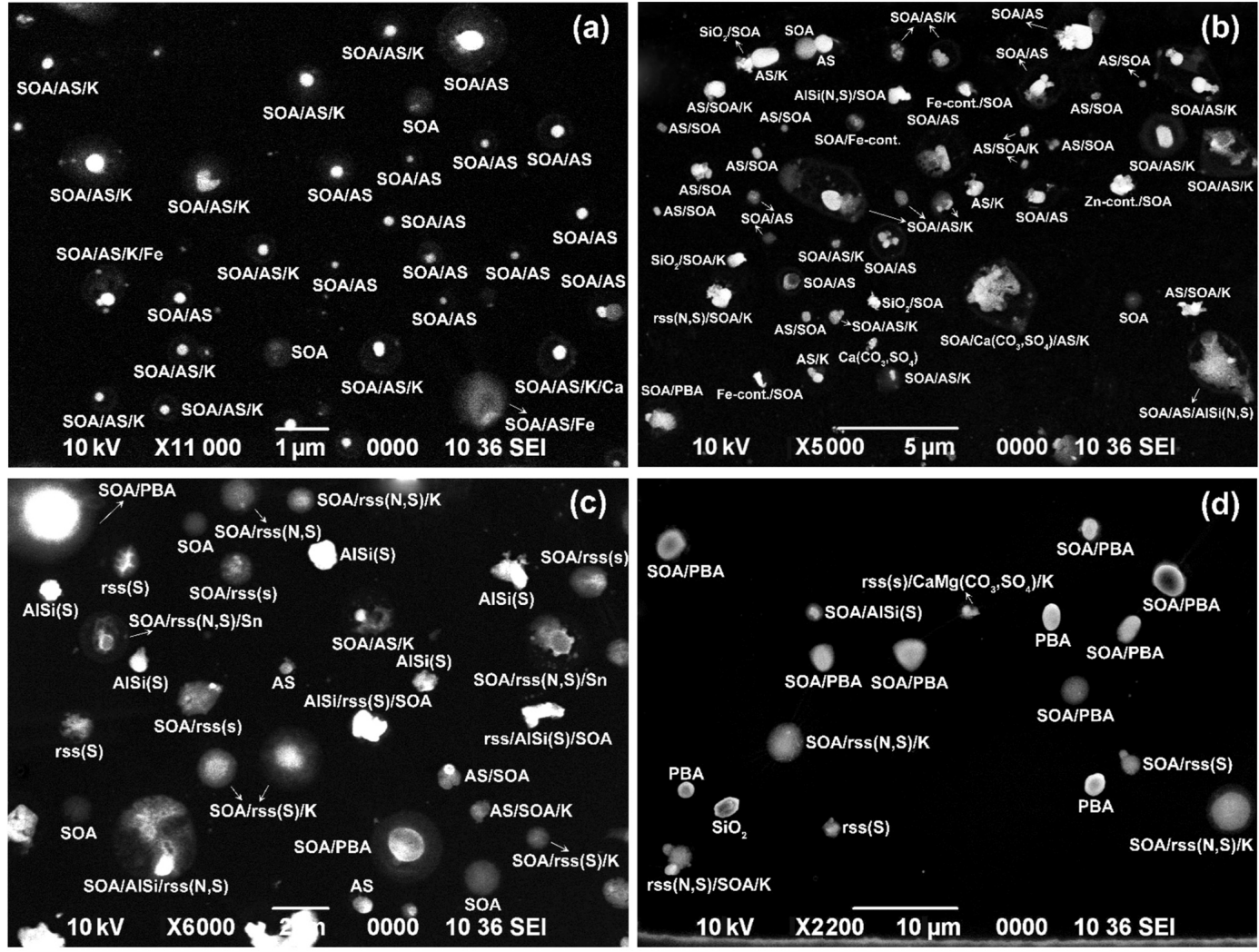

Figure 4. Typical SEM images of aerosol particles for (a) stage $1\left(\mathrm{PM}_{0.25-0.5}\right)$ of the SA2 sample, (b) stage $2\left(\mathrm{PM}_{0.5-1.0}\right)$ of the SA4 sample, (c) stage $3\left(\mathrm{PM}_{1-2}\right)$ of the SA1 sample, and (d) stage $4\left(\mathrm{PM}_{2.0-4.0}\right)$ of the SA4 sample, collected at the ATTO site. For convenience, ammonium sulfate, secondary organic aerosol, aluminosilicates, and reacted sea salt are denoted as "AS", "SOA", "AlSi", and "rss", respectively.

Maskey et al., 2010). As TEM grids are hydrophobic due to the thin carbon layer over the formvar film, the aqueous droplet aerosols appear circular on the TEM grids (Eom et al., 2014; Maskey et al., 2010), suggesting that SOAs were collected as aqueous droplets at the time of particle sample collection. Recent studies also reported that most submicron SOA particles in the Amazon basin are water-soluble organic aerosols (WSOAs) rather than semisolid or solid aerosols under the background conditions that are typically met during the wet season (Bateman et al., 2016, 2017). The X-ray spectrum of a typical pure SOA, as shown in Fig. 6a, showed considerably higher levels of the $\mathrm{CX}$-ray peak intensity compared to that from the formvar/carbon film of the TEM grids, resulting in the unambiguous identification of SOA particles based on their SEIs and X-ray spectral data.

\subsubsection{Ammonium sulfate (AS) particles}

Ammonium sulfate particles were observed abundantly in the ATTO and Manaus samples, mostly as mixtures with secondary organics. Ammonium sulfate particles appear bright and crystalline on the SEIs before the X-ray measurements, both for pure airborne and standard ammonium sulfate par- ticles, as shown in Fig. $6 \mathrm{~b}$ and f, respectively. The standard ammonium sulfate particles were deposited on TEM grids by the nebulization of a $0.1 \mathrm{M}$ ammonium sulfate solution. As shown in the inset in Fig. $6 \mathrm{~b}$ and f, after the X-ray measurements, they show somewhat darkened SEIs with black holes, due to electron beam damage, at the places where the electron beam hits. As the ammonium sulfate particles are electron beam sensitive (Geng et al., 2010; Worobiec et al., 2003; Huang and Turpin, 1996), their X-ray spectral signature is the presence of a significant S X-ray peak, as shown for both pure airborne and standard particles on the TEM grids. The $\mathrm{N}$ X-ray peak was often not detected, particularly for small particles because the $\mathrm{NH}_{4}^{+}$moiety is especially prone to damage by electron beams.

Ambient urban and rural sulfates act as a sink for ammonia, of which the sources are largely animal waste, fertilizer application, soil release, and industrial emissions. The most common form is ammonium sulfate. On the other hand, if ammonia is scarce in the air, sulfates would be in more acidic forms, such as $\mathrm{NH}_{4} \mathrm{HSO}_{4}$ or $\mathrm{H}_{2} \mathrm{SO}_{4}$ (Millstein et al., 2008). The acidic $\mathrm{NH}_{4} \mathrm{HSO}_{4}$ and $\mathrm{H}_{2} \mathrm{SO}_{4}$ particles have been reported to be more hygroscopic than pure ammonium sulfate (Pósfai et al., 1998). Hence, they can be spread over the 

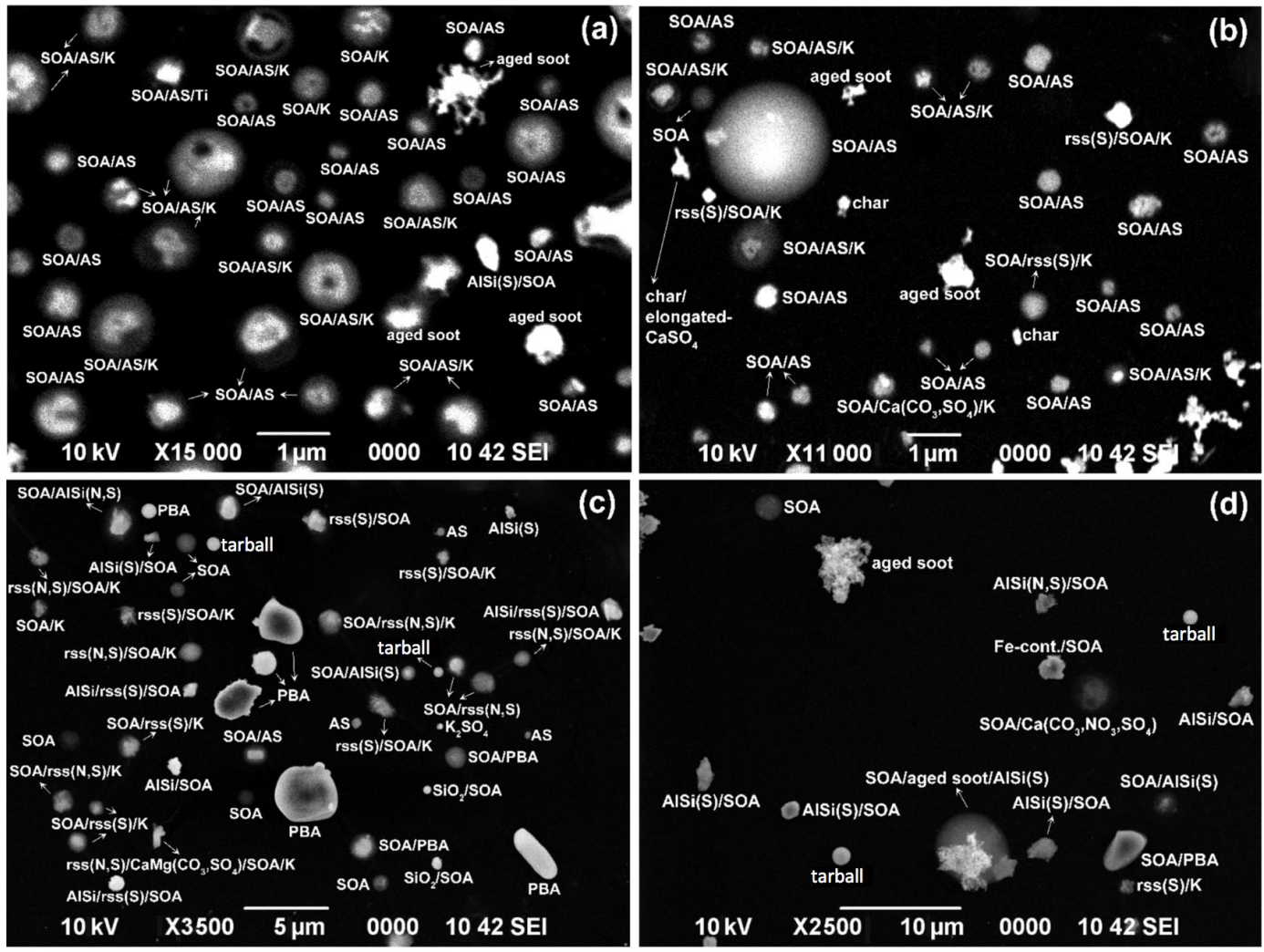

Figure 5. Typical SEM images of aerosol particles for (a) stage $1\left(\mathrm{PM}_{0.25-0.5}\right)$ of the SM1 sample, (b) stage $2\left(\mathrm{PM}_{0.5-1.0}\right)$ of the SM2 sample, (c) stage $3\left(\mathrm{PM}_{1-2}\right)$ of the SM1 sample, and (d) stage $4\left(\mathrm{PM}_{2.0-4.0}\right)$ of the SM3 sample, collected at the Manaus site. For convenience, ammonium sulfate, secondary organic aerosol, aluminosilicates, and reacted sea salt are denoted as "AS", "SOA", "AlSi", and "rss", respectively.

collecting substrate (formvar/carbon film). In addition, acidic sulfate particles can have unique halo rings in their morphology (Buseck and Pósfai, 1999). The crystalline structure of the ammonium-sulfate-containing particles observed in this study suggests that they are sulfates fully neutralized with ammonia. In addition, the Raman spectra of airborne particles exhibiting this morphology were obtained on a single-particle basis to confirm that they are ammonium sulfate. As shown in Fig. 7a, the Raman peak at $975 \mathrm{~cm}^{-1}$ of the airborne particle is characteristic of ammonium sulfate (Ling and Chan, 2007), which was also confirmed by Raman spectroscopy on standard ammonium sulfate particles. Characteristic Raman peaks for $\mathrm{NH}_{4} \mathrm{HSO}_{4}, \mathrm{~K}_{2} \mathrm{SO}_{4}$, $\mathrm{CaSO}_{4} 2 \mathrm{H}_{2} \mathrm{O}, \mathrm{CaSO}_{4}, \mathrm{Na}_{2} \mathrm{SO}_{4}$, and $\mathrm{MgSO}_{4} x \mathrm{H}_{2} \mathrm{O}(x=1-$ $7,11)$ were reported to be at 1010 and 1042, 983, 1008, 1014 and 1025, 992, and $984-1046 \mathrm{~cm}^{-1}$, respectively (Fung and Tang, 1988; Wang et al., 2006; Mabrouk et al., 2013; Prieto-Taboada et al., 2014). The sloping baseline in the Raman spectrum of the airborne particle was attributed to the fluorescence from organics, indicating the presence of organic compounds (Sobanska et al., 2012), probably from SOA. For aerosols collected on Ag foil at the ATTO site on 10 June 2014, ammonium sulfate is the major species with some organics and minerals such as kaolinite, for the bulk aerosols in the size range of $0.25-0.5 \mu \mathrm{m}$, based on their $\mathrm{X}$-ray, attenuated total reflection Fourier-transform infrared spectroscopy (ATR-FTIR), and Raman spectra (Fig. 7b). A study of the samples collected in the central Amazon basin during the wet season from February to March 2008 reported that ammonium was not sufficient to fully neutralize sulfates so that ammonium bisulfate would be present in the Amazon rainforest (Chen et al., 2015), whereas other studies reported that sulfates are sufficiently neutralized with ammonia in the fine and coarse fractions during both the wet and dry seasons (Andreae et al., 2015; Martin et al., 2010b; Fuzzi et al., 2007; Mace at al., 2003). The different results may be due to different sampling places and seasons. In this study, ammonium sulfate is dominant over ammonium bisulfate.

Previous studies have shown that the sulfate aerosols over the Amazon forest are predominantly from marine and terrestrial biogenic sources, with comparable contributions from marine and terrestrial biogenic emissions (Andreae et al., 1990). Sulfate originates from biogenic sources in the rainforest, i.e., dimethyl sulfide (DMS), $\mathrm{H}_{2} \mathrm{~S}$, and $\mathrm{CS}_{2}$ emitted by plants and microorganisms, which can be oxidized to sulfate (Andreae et al., 1990, 2015; Martin et al., 2010b). The rain- 

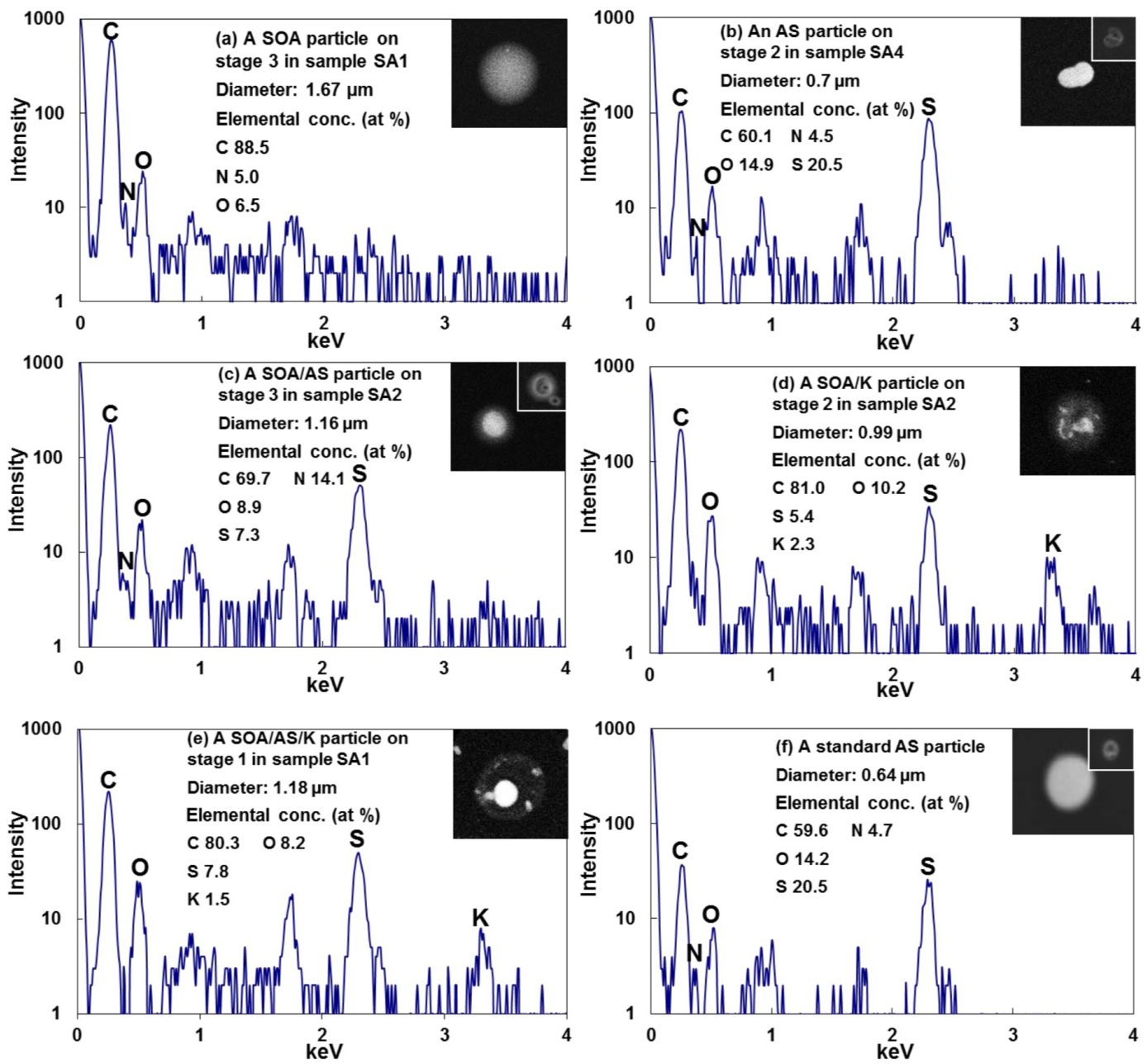

Figure 6. SEIs, X-ray spectra, and element atomic concentrations of SOA, ammonium sulfate (AS), and mixture particles. The inset images in (b), (c), and (f) show the beam damage on the particles after X-ray measurements.

forest ecosystem in the central Amazon can act as a source of DMS to the atmosphere throughout the year (Jardine et al., 2015). Several studies have reported that marine DMS transported from the Atlantic Ocean contributes significantly to the sulfate levels in the Amazon basin (Gregory et al., 1986; Andreae et al., 1990; Martin et al., 2010a). In addition, there is some sulfate from long-range transport across the Atlantic including that from the African volcanic emissions (Saturno et al., 2018) and minor upwind anthropogenic sources.

The nitrogen cycle is essential for organisms and some bacteria to fix the gaseous $\mathrm{N}_{2}$ in the air to $\mathrm{NH}_{4}^{+}$for their own biosynthetic processes (Kim and Rees, 1994; Bazzaz, 1998; Kellerhals et al., 2010). In addition, some microorganisms produce enzymes to release nitrogen as $\mathrm{NH}_{4}^{+}$during the nitrogen mineralization process, which is important in tropical rainforest soils, where dead plants and animal matter accumulate continuously (Wright, 1996; Neill et al., 1999). A high level of $\mathrm{NH}_{4}^{+}$in tropical rain contributes significantly to the nitrogen influx in the rainforest soils (Jordan et al.,
1982). The $\mathrm{NH}_{4}^{+}$species can be evaporated as gaseous $\mathrm{NH}_{3}$ from surface soils, particularly from leaf litter, resulting in a strong $\mathrm{NH}_{3}$ emission source as well as stomatal $\mathrm{NH}_{3}$ emission of plants as another natural source in forest ecosystems (Sutton et al., 2009, 2013; Hansen et al., 2017). On the other hand, $\mathrm{NH}_{4}^{+}$species in rainforest soils might become airborne immediately after rainfall, similar to the way that airborne organic particles are produced directly from soils by raindrop impaction (Wang et al., 2016). The wetness of forest surfaces is significant in controlling both the deposition and emission of atmospheric $\mathrm{NH}_{3}$ (Hansen et al., 2015). As ammoniumsulfate-containing particles were also observed abundantly in the samples collected at the Manaus site, they were influenced strongly by the surrounding Amazonian forest and/or generated by anthropogenic activities in the urban environment. In the urban environment, anthropogenic ammonium sulfate is mainly formed by gaseous reactions among $\mathrm{SO}_{2}$ emitted from coal-fired plants and industrial activities, $\mathrm{NH}_{3}$ emitted from human and animal activities and fertilization in 
the fields, and oxidants (e.g., $\mathrm{O}_{3}$ and $\mathrm{OH}$ radical) ( $\mathrm{Li}$ et al., 2016; Geng et al., 2017).

\subsubsection{SOA and AS mixture particles}

In this study, most airborne submicron SOAs were observed to be internally mixed with ammonium sulfate, particularly for the samples collected at the ATTO site. Figure $6 \mathrm{c}$ shows that a typical SOA and AS mixture particle has the crystalline, bright ammonium sulfate moiety in the center surrounded by circular, gray organic species. The circular morphology of the organic species strongly suggests that the organic species are SOAs, as stated above. As efflorescence and deliquescence relative humidity (ERH and DRH) of ammonium sulfate species are 30\%-40\% and 80\%, respectively (Yeung and Chan, 2010), and the ambient RH was always above $55 \%$ during sampling for the ATTO and Manaus samples, the ammonium sulfate would be mostly in aqueous droplets at the time of sample collection, rather than in crystalline form, as indicated by their overall circular shape. When the particle samples were under dry conditions either during sample storage or in the vacuum chamber of the SEM instrument, the ammonium sulfate species crystallized, resulting in core-shell structures of organic and inorganic mixture aerosols. When the ambient $\mathrm{RH}$ is low enough to make the ammonium sulfate species crystallize in the atmosphere, the organic and inorganic mixture aerosols would similarly be present as core-shell structures.

Some of the SOA and AS mixture particles were also mixed with $\mathrm{K}$ salts. As shown in Fig. 6d and e, their morphology was similar to that of the SOA and AS mixture particles, but their X-ray spectra revealed the presence of $\mathrm{K}$ and an elevated S level compared to those of the SOA and AS mixture particles, suggesting that the $\mathrm{K}$ is associated mostly with $\mathrm{SO}_{4}^{2-}$. The shoulder Raman peak of the airborne ammonium sulfate particle at $982 \mathrm{~cm}^{-1}$ (Fig. 7a), which is indicative of the $\mathrm{K}_{2} \mathrm{SO}_{4}$ moiety (Mabrouk et al., 2013), also suggests that the $\mathrm{K}$ salts are most probably $\mathrm{K}_{2} \mathrm{SO}_{4}$. A previous study reported that small $\mathrm{K}$-salt-rich particles can act as seeds for SOA formation in the Amazon basin and $\mathrm{K}$ salts are present ubiquitously in Amazonian SOAs, with their content being higher in the morning hours and for smaller SOAs (Pöhlker et al., 2012). On the other hand, among the 843 submicron SOA and/or ammonium sulfate particles collected at the ATTO site, only $31 \%$ contained $\mathrm{K}$ salts, which is probably because the samples were collected in the afternoon and/or the analyzed particles were larger than $0.25 \mu \mathrm{m}$ so that the K-salt content may be below the detection limit of EDX ( $\sim 0.1$ w.t. \%). In the Manaus samples, a total of 199 submicron SOA and/or ammonium sulfate particles were observed, of which approximately $40 \%$ contained K salts, suggesting that the Manaus samples were influenced strongly by the surrounding rainforest as supported by the backward trajectories (Fig. 2e-g), where K salts may be mostly of a biogenic origin in the rainforest. The organic moiety is often mixed in- ternally with aged sea salts, mineral dust, and PBAs, which will be described below.

\subsubsection{Mineral dust particles}

The typical mineral dust particles include aluminosilicate, quartz $\left(\mathrm{SiO}_{2}\right)$, calcite $\left(\mathrm{CaCO}_{3}\right)$, dolomite $\left(\mathrm{CaMg}\left(\mathrm{CO}_{3}\right)_{2}\right)$, and $\mathrm{TiO}_{2}$ (Geng et al., 2009, 2011). They appear irregular and bright on the SEIs (Fig. 8). Various types of mineral particles from Saharan dust contribute significantly to the nutrient cycles in the Amazon rainforest (Talbot et al., 1990; Abouchami et al., 2013; Rizzolo et al., 2017). Mineral dust tends to provide reactive surfaces for heterogeneous reactions with trace atmospheric gases, such as $\mathrm{SO}_{2}$ and $\mathrm{NO}_{x}$, leading to chemical modifications of the particles that ultimately affect the atmospheric chemical balance and photochemical cycle (Sullivan et al., 2007; Chen et al., 2011). Modification of the physicochemical properties of particles can alter their optical, chemical, and hygroscopic properties (Sullivan et al., 2007; Geng et al., 2014). If some components in them (particularly $\mathrm{Ca}$-containing species) react with airborne $\mathrm{SO}_{2}$ and $\mathrm{NO}_{x}$ in the presence of moisture or with secondary acids, such as $\mathrm{H}_{2} \mathrm{SO}_{4}, \mathrm{HNO}_{3}$, and $\mathrm{HCl}$, they are regarded as reacted or aged ones. The reacted or aged ones can contain either nitrates, sulfates, or both (Geng et al., 2014, 2017; Li et al., 2016). In the Amazon samples, almost all the mineral dust particles were aged ones, as shown in Fig. 8, where an aluminosilicate and a carbonatesilica mixture particle containing sulfate are shown. The Scontaining aged mineral dust particles outnumbered the $\mathrm{N}$ containing and both $\mathrm{N}$ - and S-containing ones for the ATTO samples, whereas they were comparable to both the N- and Scontaining ones for the Manaus samples, as shown in Fig. 9a, indicating the predominance of sulfates over nitrates for the reaction of mineral dust particles at the ATTO site and somewhat significant influence of nitrates at the Manaus site. The nitrates for the Manaus samples may be formed from nitrogen oxides emitted from the vehicles and coal-fired power plants (Geng et al., 2014, 2017; Li et al., 2016). The mineral particles might be mixed or covered with SOA and/or ammonium sulfate and gradually become aged under a high $\mathrm{RH}$ in the rainforest. Some mineral particles were also mixed with sea-salt particles during their transport to the Amazonian area across the Atlantic Ocean.

\subsubsection{Reacted (aged) sea salts}

The fresh sea-salt particles can react with gas-phase sulfur and nitrogen oxides to contain sulfate and nitrate, respectively (ten Brink, 1998). During the process, chlorine may be removed completely if the reaction is complete (Laskin et al., 2003). All sea-salt particles observed in the ATTO and Manaus samples were reacted ones. Figure 10a shows the X-ray spectrum, atomic concentration, and SEI of a typical aged sea-salt particle, where the presence of $\mathrm{Na}, \mathrm{Mg}$, 

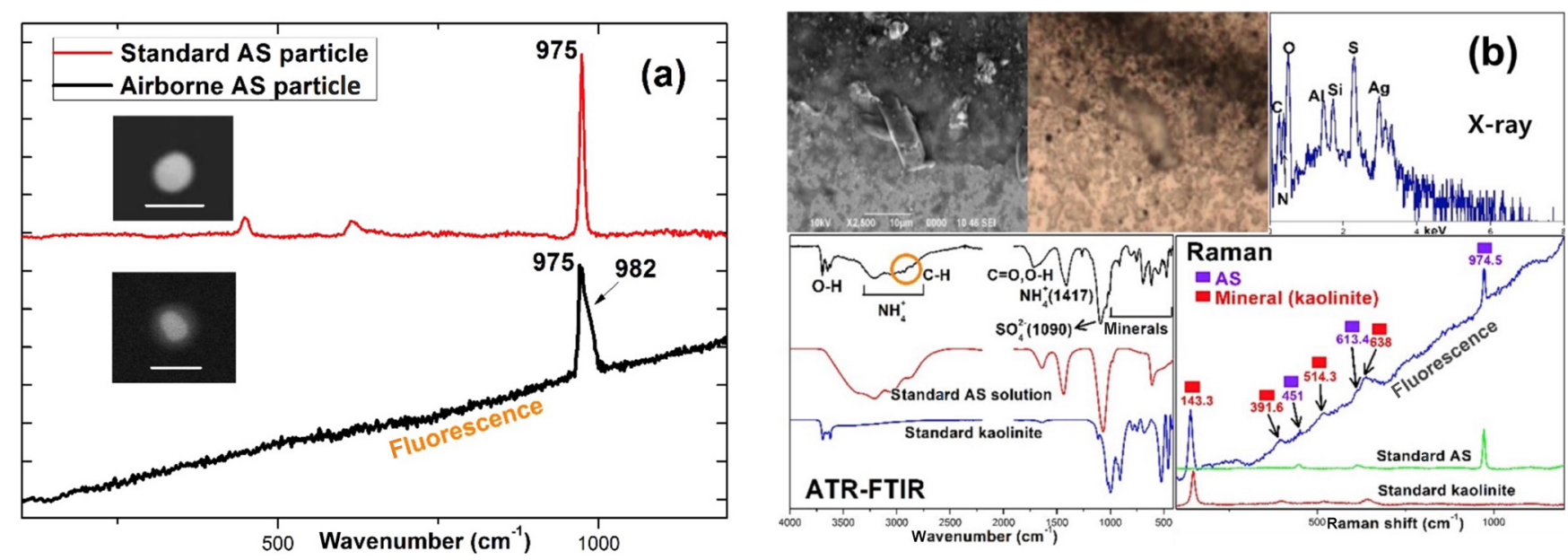

Figure 7. (a) Raman spectra of standard and airborne ammonium sulfate (AS) particles, which were rescaled for clarity. The inset SEI images are for standard and airborne AS particles where the scale bar is $1 \mu \mathrm{m}$. The shoulder peak of $\mathrm{SO}_{4}^{2-}$ at $982 \mathrm{~cm}^{-1}$ in the airborne AS particles is from $\mathrm{K}_{2} \mathrm{SO}_{4}$; (b) SEI, optical images, X-ray, ATR-FTIR, and Raman spectra of an overloaded PM $0.25-0.5$ sample collected at the ATTO site on 10 June 2014. X-ray, ATR-FTIR, and Raman spectra indicate that AS, organics, and minerals are the major components of the submicron sample. The sloping baseline in the airborne Raman spectrum is due to the fluorescence from organic compounds.
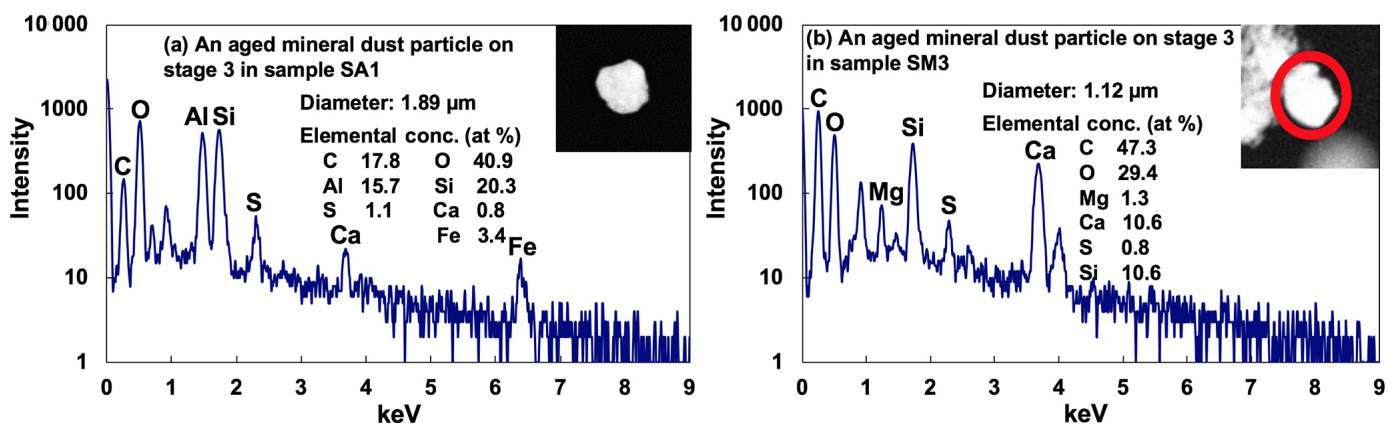

Figure 8. SEIs, X-ray spectra, and element atomic concentrations of aged mineral dust particles.

and $\mathrm{Cl}$ indicates its marine origin (Geng et al., 2014) and the presence of $\mathrm{S}$ and $\mathrm{C}$ indicates that it is mixed with sulfates and organics. The irregular and somewhat bright SEI is typical of the aged sea-salt particles. As shown in Fig. 9b, S-containing sea salts outnumbered N-containing and both $\mathrm{N}$ - and S-containing ones for the ATTO samples, indicating the predominance of sulfates over nitrates for the reaction of sea-salt particles. The S-containing particles are comparable in abundance to both the N- and S-containing ones at the Manaus site (Fig. 9b). The sea-salt particles may also become mixed with ammonium sulfate over the rainforest and become S-containing ones. Among overall 275 reacted sea salts containing sulfate and nitrate and organics, $71 \%$ of them were mixed with $\mathrm{K}$ salts, as shown in Fig. 10b. The presence of $\mathrm{K}$ salts in the reacted sea-salt particles indicates that the mixing of the $\mathrm{K}$ salts of biogenic origin would happen in the rainforest during long-range transport because of the minimal biomass burning influence during the wet season, although it was reported that a strong biomass burning smoke was transported from Africa to South America during the wet season (Baars et al., 2011) so a part of the observed $\mathrm{K}$ salts could be associated with biomass burning aerosols from Africa. In addition, several elongated $\mathrm{CaSO}_{4}$ particles, as shown in Fig. 10c, were detected in both ATTO and Manaus samples, all of which contain a small amount of $\mathrm{Na}$. Their elongated shape and the presence of $\mathrm{Na}$ strongly indicates that they were from the sea, possibly the Atlantic Ocean, not from the soil (Eom et al., 2016).

\subsubsection{Primary biological aerosol (PBA) particles}

PBA particles like fungal spores can be identified easily based on their unique morphology and the presence of their characteristic chemical elements (Geng et al., 2009; Martin et al., 2010a; Pöschl et al., 2010). The PBA particle shown in Fig. 11a has a unique oval morphology and the majority of $\mathrm{C}$ together with the characteristic small amounts of $\mathrm{N}, \mathrm{P}, \mathrm{S}, \mathrm{Cl}$, and $\mathrm{K}$. PBA particles are relatively large (diameter $>2.0 \mu \mathrm{m}$ ) so they are abundant in stage 4 samples 
(a) Aged mineral dust
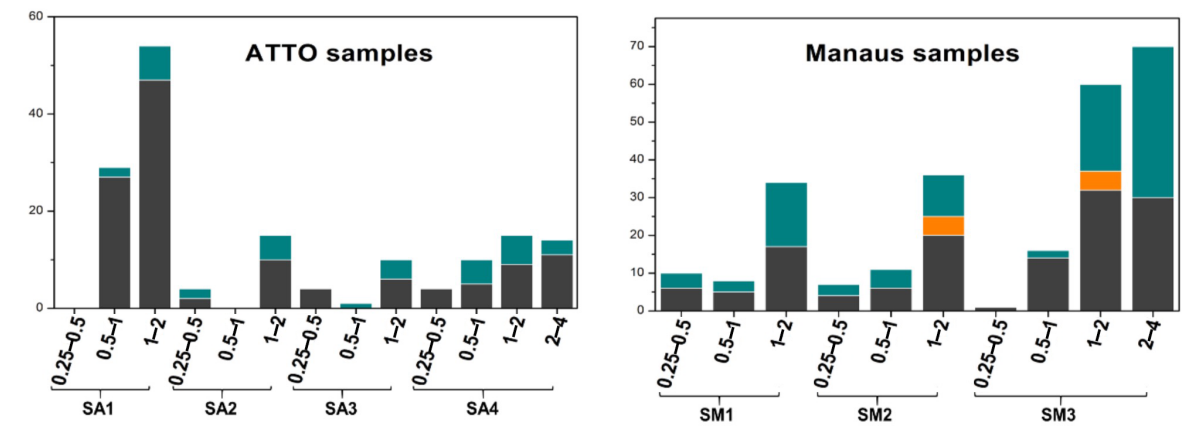

(b) Reacted sea salts
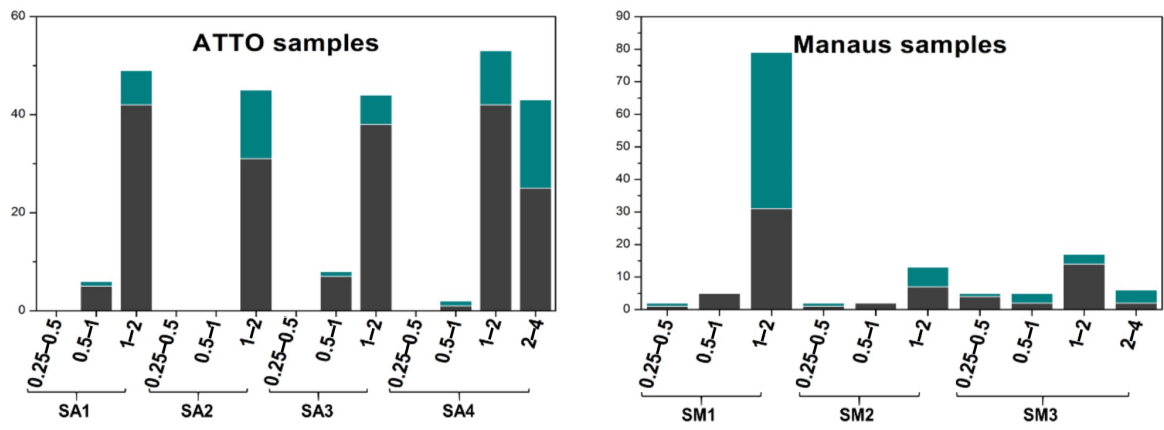

Figure 9. Number abundances of reacted sea-salt and aged mineral dust particles containing sulfates (black), nitrates (orange), and both (turquoise). The size ranges of each sample are given in the $x$ axis.

$(2.0 \mu \mathrm{m}<$ diameter $<4.0 \mu \mathrm{m})$, particularly at the ATTO site. Figure 12 shows two image fields of stage 4 samples collected at the ATTO and Manaus sites, where the PBA particles have various types of morphology and many of them are mixed with SOA. The abundant observation of PBA particles in the stage 4 sample of the Manaus site suggests the transport of the PBA particles from the rainforest to the urban area. Supermicron PBA particles were reported to be abundant over the Amazon (China et al., 2016; Moran-Zuloaga et al., 2018; Gilardoni et al., 2011). PBA particles can be pollen, bacteria, fungal and fern spores, viruses, and fragments of plants and animals emitted directly from the rainforest, showing a range of morphologies, and comprise the largest fraction of the coarse mass (Martin et al., 2010a). PBA particles appear to be the most efficient and abundant ice nuclei (Pöschl et al., 2010; Tobo et al., 2013; Haga et al., 2014). In addition, the release of nano- and submicron particles from fungal spores under high relative humidity can contribute to new particle formation and potentially affect cloud formation in the Amazon basin (China et al., 2016).

\subsubsection{Carbon-rich particles from combustion sources}

Carbon-rich particles, such as soot, tarballs, and char or coal dust, which contain more than $90 \% \mathrm{C}$ and $\mathrm{O}$ with the $\mathrm{C}$ content being dominant over $\mathrm{O}$ in low- $Z$ particle EPMA analysis
(Geng et al., 2009, 2010, 2014), were observed frequently in the Manaus samples, whereas they were rare in the ATTO samples. Based on the characteristic morphology of carbonrich particles, soot aggregates of fractal-like chain structures (Fig. 11b), tarballs of separate spherules (Fig. 11c), and chars of irregular-shaped carbon (Fig. S5, SM1-2) could be differentiated straightforwardly from each other (Geng et al., 2010, 2014; Li et al., 2016). The soot aggregates formed via a vaporization-condensation mechanism during the combustion processes vary in size from sub- to several micrometers (Chen et al., 2005, 2006). Once airborne, the complex microstructure of the soot aggregates may provide active sites for the deposition of organics and other chemical species, such as sulfates (Pósfai et al., 1999; Zhang et al., 2008), as revealed by the presence of $S$ in Fig. 11b. This results in aged soot aggregates that become compact with considerable restructuring and shrinkage (Zhang et al., 2008). Tarballs, which are a type of brown carbon (Andreae and Gelencsér, 2006; Laskin et al., 2015), usually have high C, N, and O contents with a spherical morphology (Fig. 11c), strongly indicating their formation during biomass combustion processes (Pósfai et al., 2003, 2004). Char appears compact and irregular in the SEIs; it is often mixed with minor inorganic species, such as $\mathrm{K}$ and $\mathrm{S}$, and is regarded as the incomplete combustion remnants of liquid or solid carbonaceous fuel materials that have undergone carbonization during combustion (Chen 

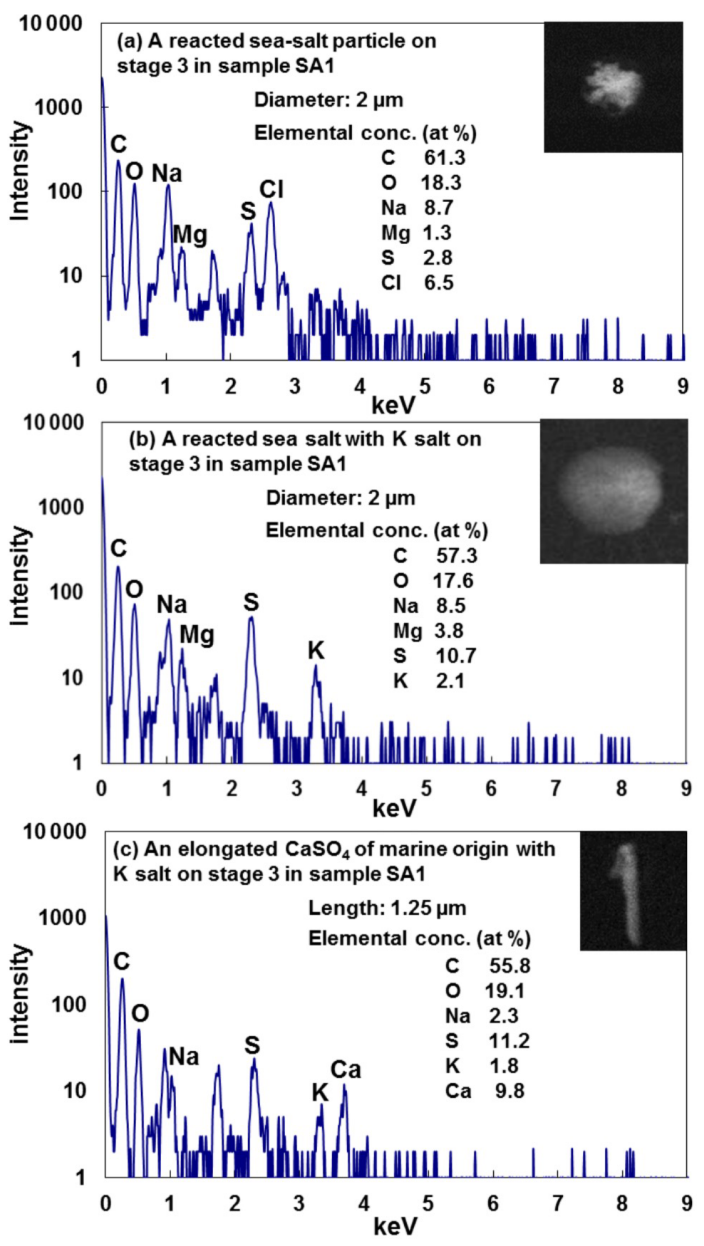

Figure 10. SEIs, X-ray spectra, and element atomic concentrations of (a) reacted sea salt, (b) reacted sea salt with K salt, and (c) elongated $\mathrm{CaSO}_{4}$.

et al., 2006). Only one soot particle was observed in all the ATTO samples, whereas soot, tarball, and char or coal dust particles were abundant in the submicron Manaus samples, suggesting that the ATTO samples are barely affected by the anthropogenic carbon-rich particles generated in Manaus.

\subsubsection{Fly ash particles}

As shown in Fig. 11d, fly ash particles are glassy spheres, composed mainly of $\mathrm{O}, \mathrm{Si}$, and $\mathrm{Al}$ with minor components such as $\mathrm{Fe}$ and $\mathrm{Ca}$, which can be identified clearly by their spherical shape and bright contrast on SEIs. The fly ash particles are different from tarballs having only $\mathrm{C}$ and $\mathrm{O}$ signals in their X-ray spectra, even though both are generated during the combustion processes (Geng et al., 2017). They were observed only in the Manaus samples, reflecting their anthropogenic origin.

\subsubsection{Heavy-metal-containing particles}

Heavy-metal-containing (HM) particles, such as $\mathrm{Ni}^{-}$, Ti-, $\mathrm{Zn}$-, and Fe-containing ones, appear bright and irregular on SEM images, as shown in Fig. 11e and f, and were observed mostly in the fine fraction with more than a half of them being Fe-containing particles both in the ATTO and Manaus samples. The Fe-containing particles in the ATTO samples were observed to be associated with SOA (and ammonium sulfate), as shown in Fig. 11f, indicating its mixing with the species of a biogenic emission origin. Sahara mineral dust has been reported to be essential for the nutrient cycles in the Amazon rainforest because many types of minerals are carried and transported into the rainforest, in which $\mathrm{Fe}$ is one of the important micronutrients in a Fe-limited rainforest (Rizzolo et al., 2017). Among all the mineral dust particles observed in the samples, approximately $40 \%$ of them contain Fe. The HM particles can also be of anthropogenic origin: emitted from the streets or road surface as brake dust, road paint particles, diesel exhaust particles, construction materials, and/or car catalyst materials (Qiao et al., 2016).

\subsection{Relative abundances of particle types observed in the ATTO and Manaus samples}

Figure 13 shows the relative abundance of the nine different particle types observed in the ATTO and Manaus samples. In the stage 1 samples $(0.25-0.5 \mu \mathrm{m}$ size $)$ of SA1SA4 collected at the ATTO site, almost all the particles were SOA and AS mixtures. In the stage 2 samples (0.5$1.0 \mu \mathrm{m}$ size), SOA and AS mixture particles were dominant for the SA2 and SA3 samples. In the stage 2 samples of samples SA1 and SA4, SOA and AS mixture particles were most abundant, followed by pure ammonium sulfates, aged mineral dust, and pure SOA particles. In the stage 2 samples of SA1-SA4, the summed contents of SOA and ammonium sulfate were $73 \%, 99 \%, 85 \%$, and $82 \%$, respectively, suggesting that SOA and AS are the predominant species in submicron aerosols collected at the ATTO site. The observation of abundant submicron SOAs, which constitute a significant fraction of fine aerosol mass during the wet season at the rainforest, has been reported (Chen et al., 2015; Gilardoni et al., 2011). Although ammonium sulfates were reported to be present in significant quantities in the Amazon basin (Andreae et al., 2015; Chen et al., 2015; Fraund et al., 2017), this study emphasizes the observation of the predominant submicron ammonium sulfates mixed with SOA.

In the stage 2 samples, aged mineral dust and sea salts for the SA1 sample, reacted sea salts for the SA3 sample, and aged mineral dust and sea salts for the SA4 sample were significantly observed, suggesting that the samples from outside the Amazon rainforest have different influences because the mineral dust and sea-salt particles were all aged ones. The influences from outside were observed more clearly for supermicron aerosols at the ATTO site. In the stage 3 sam- 

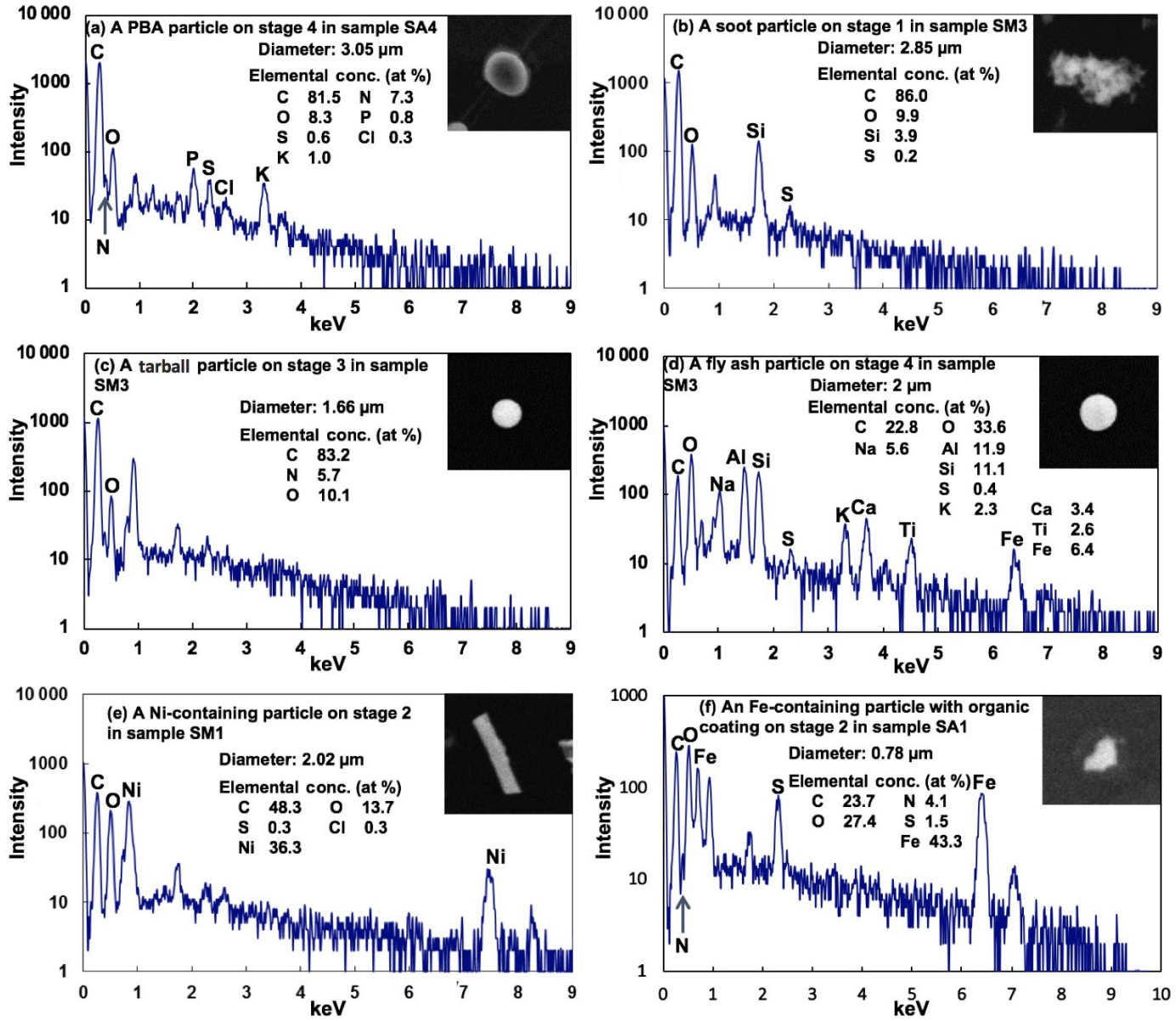

Figure 11. SEIs, X-ray spectra, and element atomic concentrations of (a) PBA, (b) soot, (c) tarball, (d) fly ash, (e) Ni-containing particles, and (f) Fe-containing particles.

ples (1.0-2.0 $\mu \mathrm{m}$ size) of SA1-SA4, reacted sea-salt particles and aged mineral dust particles were abundantly observed, although the summed relative abundances of SOA and ammonium sulfate were $28 \%, 43 \%, 58 \%$, and $50 \%$, respectively, indicating that SOA and ammonium sulfate are abundant even in supermicron ATTO aerosols. As all the mineral dust particles were aged, they are not of local origin, and the observation of a high content of aged mineral dust particles in sample SA1 highlights the importance of long-range transatlantic transport (see the fast-moving air masses from the Atlantic Ocean for the SA1 sample in Fig. 2a, although a single backtrajectory cannot confirm the African origin of the aged mineral dust particles). Many studies have examined the influence of the Saharan dust particles over the Amazon rainforest region, starting with the measurements made during the ABLE-2B campaign (Talbot et al., 1990; Swap et al., 1992). Mineral dust is imported most frequently to the rainforest in March and April (Martin et al., 2010a; MoranZuloaga et al., 2018), which increases the ground-based soil dust element levels significantly (Artaxo et al., 2013). In this study, approximately $70 \%$ and $90 \%$ of the reacted sea-salt and mineral dust particles in the ATTO and Manaus samples, respectively, were either mixed or coated with organic matter in the Amazon basin and/or during the long-range transport.

PBA particles, which are from the rainforest, are sometimes observed in the stage 3 samples for the SA1-SA4 samples. In the stage 4 sample (2.0-4.0 $\mu \mathrm{m}$ size) of the SA4 sample, the most abundant particle type was PBA, followed in order by reacted sea salt, SOA, aged mineral dust, and ammonium sulfate, where both (i) PBA, SOA, and ammonium sulfate particles of a local origin and (ii) the reacted sea-salt and mineral dust particles from the outside are considerably present. In summary, the aerosols collected at the ATTO site are mostly SOA and ammonium sulfate of a local origin in the submicron fraction, although some of the submicron sulfate is of marine and distant origin, whereas aerosols of both local and distant origins are significant in the supermicron fraction.

The aerosols collected at the Manaus site were diverse compared to those at the ATTO site. As shown in Fig. 13, for the stage 1 and 2 samples, SOA and ammonium sulfate particles, including their mixture, were the major components for 

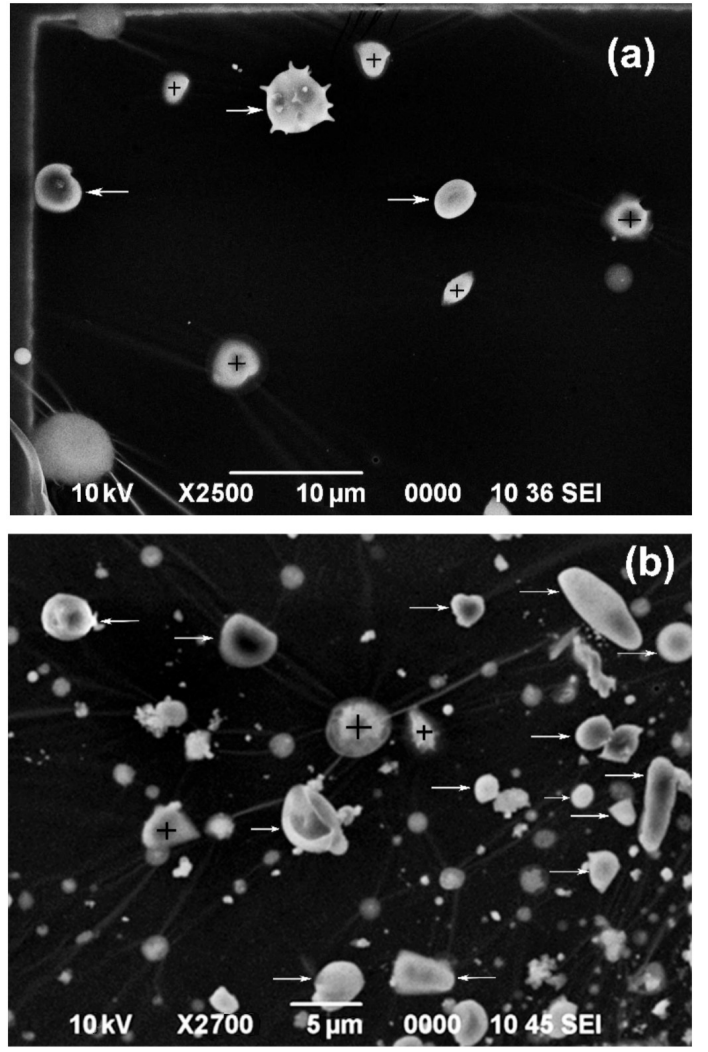

Figure 12. Typical SEIs of PBA particles from stage 4 of the (a) SA4 and (b) SM3 samples. PBA and PBA-SOA mixture particles are marked with $(\rightarrow)$ and $(+)$, respectively.

the SM1 and SM2 samples, whereas they were relatively less abundant for the SM3 sample. As SOA and ammonium sulfate particles can be from the surrounding rainforest areas in addition to local anthropogenic sources, samples SM1-SM3 collected at the Manaus site appear to be influenced from the outside in the order of samples SM1 $>$ SM2 $>$ SM3. In addition, considerable amounts of submicron carbonaceous particles were observed, such as soot, char, and tarballs, which are of a local origin. The most abundant submicron aerosols for sample SM3 were carbonaceous ones, indicating that the local influence to the samples is in the order of SM3 $>$ SM2 > SM1. Samples SM1 and SM2 were collected during and just after a national holiday, respectively, when all the institutions (private and public) were closed during that day, so the traffic was quite low, similar to a weekend or vacation period. Sample SM3 was collected during a regular working day, so sample SM3 is the only sample actually exposed to the high traffic of light vehicles in the area.

In supermicron Manaus aerosols, PBA particles, aged mineral dust, and reacted sea salts in addition to SOA and carbonaceous particles are abundant. In the stage 3 aerosols of the SM1 sample, the most abundant particles were reacted sea salts, followed by aged mineral dust, SOA, ammonium sulfate, and PBA particles, which also indicates the strong influence on the SM1 sample from the outside. In stage 3 aerosols of the SM2 sample, the most abundant particles were SOA, followed in order by aged mineral dust, reacted sea salt, PBA, carbonaceous particles, and ammonium sulfate, which also indicates the strong influence on the SM2 sample from the surrounding rainforest areas. In the stages 3 and 4 aerosols of the SM3 sample, the most abundant particles were aged mineral dust (36\% and 52\% for stages 3 and 4, respectively), followed by carbonaceous particles, PBA, SOA, and reacted sea salt. As the aged seasalt contents were relatively low (10\% and $4 \%$ for stages 3 and 4 , respectively), most of the aged mineral dusts appear to be of a local origin. Fly ash and heavy-metal-containing particles of an anthropogenic local origin were considerable in the Manaus samples, i.e., they were observed in the range of $3 \%-7 \%$ relative abundances in the Manaus samples. In particular, soot particles of an anthropogenic origin were observed ubiquitously in all the Manaus samples. Among the samples, the aerosols collected at the Manaus site were different. The SM1 sample was influenced most strongly from the outside, including the surrounding rainforest and transatlantic transport. The SM2 sample has some influences by local sources as well as from the outside. The SM3 sample contains mainly aerosols of an anthropogenic local origin in the submicron fraction and some influences from the outside in the supermicron fraction. Figure $2 \mathrm{e}$ and $\mathrm{f}$ shows that the backward trajectories at heights of 100 and $500 \mathrm{~m}$ are further from the outside in the order of SM1 $>$ SM2 $>$ SM3, which is consistent with the characteristics of submicron and supermicron aerosols of the SM1-SM3 samples.

\section{Conclusions}

In this study, aerosol samples collected in the Amazonian rainforest and Manaus, Brazil, during the 2012 wet season were investigated on a single-particle basis using low- $Z$ particle EPMA. The aerosol particles were classified into nine particle types based on their morphology on SEIs together with the elemental concentrations of a total of 3162 individual particles: (i) secondary organic aerosols (SOA); (ii) ammonium sulfate (AS) particles; (iii) SOA and AS mixture particles; (iv) aged mineral dust; (v) reacted sea salts; (vi) primary biological aerosol (PBA) particles; (vii) carbon-rich or elemental carbon (EC) particles such as soot, tarball, and char; (viii) fly ash particles; and (ix) heavy metal (HM, such as $\mathrm{Fe}, \mathrm{Zn}, \mathrm{Ni}$, and $\mathrm{Ti}$ )-containing particles. For submicron aerosols collected at the ATTO site, the SOA and AS mixture particles were predominant (50\%-94\% in relative abundance) with the summed contents of SOA and ammonium sulfate being $73 \%-100 \%$. In contrast, in the supermicron aerosols at the ATTO site, aged mineral dust and sea salt $(37 \%-70 \%)$ as well as SOA and ammonium sulfate $(28 \%$ $58 \%$ ) were abundant. PBAs were observed abundantly in the $\mathrm{PM}_{2-4}$ fraction (46\%), and EC and fly ash particles were 


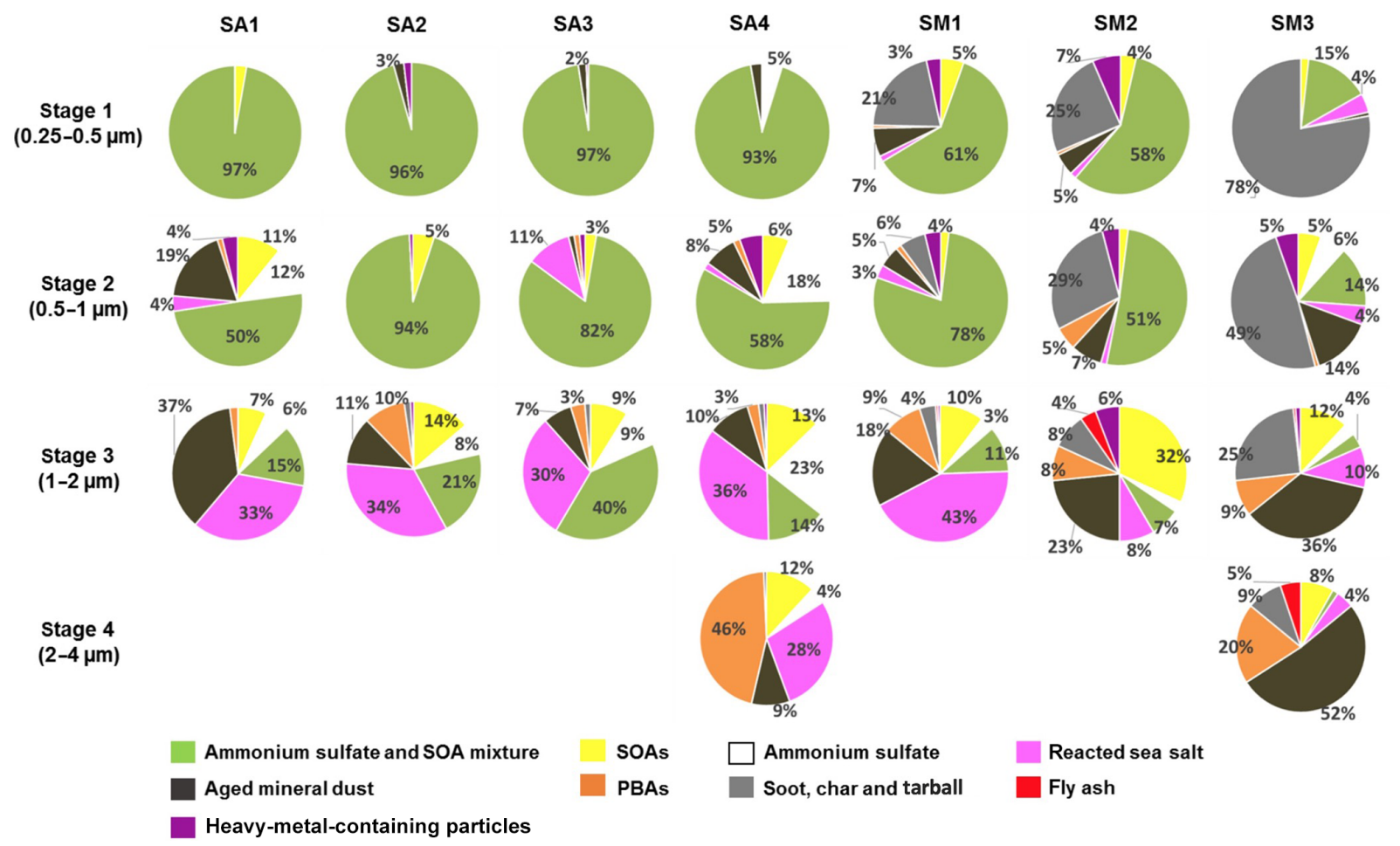

Figure 13. Relative number abundance of nine different particle types for the SA1-SA4 and SM1-SM3 samples collected at the ATTO and Manaus sites, respectively.

absent in all the fractions. An analysis of a bulk $\mathrm{PM}_{0.25-0.5}$ aerosol sample collected at the ATTO site using Raman spectroscopy and ATR-FTIR showed that ammonium sulfate, organics, and minerals are the major chemical species, which is consistent with the EPMA results.

In the submicron aerosols collected in Manaus, either SOA and ammonium sulfate $(17 \%-80 \%)$ or EC particles $(6 \%-$ $78 \%$ ) were dominant, depending on the samples. The supermicron aerosols collected in Manaus consisted mainly of aged mineral dust, reacted sea salts, PBA, SOA, ammonium sulfate, and EC particles. SOA, ammonium sulfate, and PBAs were mostly of a biogenic origin and EC and HMcontaining particles were of an anthropogenic origin. The aged mineral dust and reacted sea-salt particles, including mineral dust mixed with sea salts probably during long-range transatlantic transport, were abundant in the supermicron fractions at both sites. The submicron aerosol at the ATTO site was influenced mainly by the emission from the rainforest and its supermicron aerosols showed additional contributions from long-range transport, including the Atlantic Ocean and Sahara Desert, whereas the aerosols collected in Manaus showed different local and outside contributions among the samples. Among all the aged mineral dust and reacted sea-salt particles, sulfate-containing ones outnumbered those containing nitrates and both nitrate and sulfate in the ATTO samples, whereas $\mathrm{N}$ - and $\mathrm{S}$-containing particles were comparable to sulfate-only ones in the Manaus samples, indicat- ing the different sources and formation mechanisms of secondary aerosols, i.e., the predominant presence of sulfate at the ATTO site from biogenic emissions and elevated influences of nitrates from anthropogenic activities at the Manaus site.

Data availability. The data used in this study are available upon request; please contact Chul-Un Ro (curo@inha.ac.kr).

Supplement. The supplement related to this article is available online at: https://doi.org/10.5194/acp-19-1221-2019-supplement.

Author contributions. LW, RHMG, and CR designed the experiment. LW, XL, and HKK carried out the measurements and analyzed the data. CGGB, CIY, RAFDS, and CP organized and performed the samplings. LW, HG, RHMG, CGGB, AFLG, and CR interpreted the observations. LW, HG, RHMG, CGGB, MOA, and CR drafted the paper.

Competing interests. The authors declare that they have no conflict of interest. 
Special issue statement. This article is part of the special issue "Amazon Tall Tower Observatory (ATTO) Special Issue". It is not associated with a conference.

Acknowledgements. This study was supported by Basic Science Research Programs through the National Research Foundation of Korea (NRF) funded by the Ministry of Education, Science, and Technology (NRF-2018R1A2A1A05023254). The work of Meinrat O. Andreae and Christopher Pöhlker was supported by the German Max Planck Society (MPG). For the operation of the ATTO site, we acknowledge the support by the German Federal Ministry of Education and Research (BMBF contract 01LB1001A), the Brazilian Ministério da Ciência, Tecnologia e Inovação (MCTI/FINEP contract 01.11.01248.00), and the Coordination for the Improvement of Higher Education Personnel (CAPES) for scholarship funding (investigation) as well as the Amazon State University (UEA), FAPEAM, LBA/INPA, and SDS/CEUC/RDSUatumã. A special thanks to Claudomiro Mauricio da Silva for the support during sampling.

Edited by: Gilberto Fisch

Reviewed by: two anonymous referees

\section{References}

Abouchami, W., Näthe, K., Kumar, A., Galer, S. J. G., Jochum, K. P., Williams, E., Horbe, A. M. C., Rosa, J. W. C., Balsam, W., Adams, D., Mezger, K., and Andreae, M. O., Geochemical and isotopic characterization of the Bodélé Depression dust source and implications for transatlantic dust transport to the Amazon Basin, Earth Planet. Sc. Lett., 380, 112-123, https://doi.org/10.1016/j.epsl.2013.08.028, 2013.

Andreae, M. O.: Aerosols before pollution, Science, 315, 50-51, https://doi.org/10.1126/science.1136529, 2007.

Andreae, M. O. and Gelencsér, A.: Black carbon or brown carbon? The nature of light-absorbing carbonaceous aerosols, Atmos. Chem. Phys., 6, 3131-3148, https://doi.org/10.5194/acp-63131-2006, 2006.

Andreae, M. O., Berresheim, H., Bingemer, H., Jacob, D. J., Lewis, B. L., Li, S.-M., and Talbot, R. W.: The atmospheric sulfur cycle over the Amazon Basin, 2. Wet Season, J. Geophys. Res., 95, 16813-16824, https://doi.org/10.1029/JD095iD10p16813, 1990.

Andreae, M. O., Acevedo, O. C., Araùjo, A., Artaxo, P., Barbosa, C. G. G., Barbosa, H. M. J., Brito, J., Carbone, S., Chi, X., Cintra, B. B. L., da Silva, N. F., Dias, N. L., Dias-Júnior, C. Q., Ditas, F., Ditz, R., Godoi, A. F. L., Godoi, R. H. M., Heimann, M., Hoffmann, T., Kesselmeier, J., Könemann, T., Krüger, M. L., Lavric, J. V., Manzi, A. O., Lopes, A. P., Martins, D. L., Mikhailov, E. F., Moran-Zuloaga, D., Nelson, B. W., Nölscher, A. C., Santos Nogueira, D., T. F. Piedade, M., Pöhlker, C., Pöschl, U., Quesada, C. A., Rizzo, L. V., Ro, C.-U., Ruckteschler, N., Sá, L. D. A., de Oliveira Sá, M., Sales, C. B., dos Santos, R. M. N., Saturno, J., Schöngart, J., Sörgel, M., de Souza, C. M., de Souza, R. A. F., Su, H., Targhetta, N., Tóta, J., Trebs, I., Trumbore, S., van Eijck, A., Walter, D., Wang, Z., Weber, B., Williams, J., Winderlich, J., Wittmann, F., Wolff, S., and Yáñez-Serrano, A. M.: The Amazon Tall Tower Observatory (ATTO): overview of pilot measurements on ecosystem ecology, meteorology, trace gases, and aerosols, Atmos. Chem. Phys., 15, 10723-10776, https://doi.org/10.5194/acp-15-10723-2015, 2015.

Andreae, M. O., Afchine, A., Albrecht, R., Holanda, B. A., Artaxo, P., Barbosa, H. M. J., Borrmann, S., Cecchini, M. A., Costa, A., Dollner, M., Fütterer, D., Järvinen, E., Jurkat, T., Klimach, T., Konemann, T., Knote, C., Krämer, M., Krisna, T., Machado, L. A. T., Mertes, S., Minikin, A., Pöhlker, C., Pöhlker, M. L., Pöschl, U., Rosenfeld, D., Sauer, D., Schlager, H., Schnaiter, M., Schneider, J., Schulz, C., Spanu, A., Sperling, V. B., Voigt, C., Walser, A., Wang, J., Weinzierl, B., Wendisch, M., and Ziereis, H.: Aerosol characteristics and particle production in the upper troposphere over the Amazon Basin, Atmos. Chem. Phys., 18, 921-961, https://doi.org/10.5194/acp-18-921-2018, 2018.

Artaxo, P., Fernandas, E. T., Martins, J. V., Yamasoe, M. A., Hobbs, P. V., Maenhaut, W., Longo, K. M., and Castanho, A.: Large-scale aerosol source apportionment in Amazonia, J. Geophys. Res., 103, 31837-31847, https://doi.org/10.1029/98JD02346, 1998.

Artaxo, P., Rizzo, L. V., Brito, J. F., Barbosa, H. M., Arana, A., Sena, E. T., Cirino, G. G., Bastos, W., Martin, S. T., Andreae, M. O.: Atmospheric aerosols in Amazonia and land use change: from natural biogenic to biomass burning conditions, Faraday Discuss., 165, 203-235, https://doi.org/10.1039/C3FD00052D, 2013.

Baars, H., Ansmann, A., Althausen, D., Engelmann, R., Artaxo, P., Pauliquevis, T., and Souza, R.: Further evidence for significant smoke transport from Africa to Amazonia, Geophys. Res. Lett., 38, L20802, https://doi.org/10.1029/2011GL049200, 2011.

Bateman, A. P., Gong, Z., Liu, P., Sato, B., Cirino, G., Zhang, Y., Artaxo, P., Bertram, A. K., Manzi, A. O., Rizzo, L. V., Souza, R. A. F., Zaveri, R. A., and Martin, S. T.: Sub-micrometre particulate matter is primarily in liquid form over Amazon rainforest, Nat. Geosci., 9, 34-37, https://doi.org/10.1038/ngeo2599, 2016.

Bateman, A. P., Gong, Z., Harder, T. H., de Sá, S. S., Wang, B., Castillo, P., China, S., Liu, Y., O’Brien, R. E., Palm, B. B., Shiu, H.-W., Cirino, G. G., Thalman, R., Adachi, K., Alexander, M. L., Artaxo, P., Bertram, A. K., Buseck, P. P., Gilles, M. K., Jimenez, J. L., Laskin, A., Manzi, A. O., Sedlacek, A., Souza, R. A. F., Wang, J., Zaveri, R., and Martin, S. T.: Anthropogenic influences on the physical state of submicron particulate matter over a tropical forest, Atmos. Chem. Phys., 17, 1759-1773, https://doi.org/10.5194/acp-17-1759-2017, 2017.

Bazzaz, F. A.: Tropical Forests in a Future Climate: Changes in Biological Diversity and Impact on the Global Carbon Cycle, Climatic Change, 39, 317-336, https://doi.org/10.1023/A:1005359605003, 1998.

Buseck, P. R. and Pósfai, M.: Airborne minerals and related aerosol particles: Effects on climate and the environment, P. Natl. Acad. Sci. USA, 96, 3372-3379, https://doi.org/10.1073/pnas.96.7.3372, 1999.

Chen, H. H., Navea, J. G., Young, M. A., and Grassian, V. H.: Heterogeneous Photochemistry of Trace Atmospheric Gases with Components of Mineral Dust Aerosol, J. Phys. Chem. A, 115, 490-499, https://doi.org/10.1021/jp110164j, 2011.

Chen, Q., Farmer, D. K., Rizzo, L. V., Pauliquevis, T., Kuwata, M., Karl, T. G., Guenther, A., Allan, J. D., Coe, H., Andreae, M. O., Pöschl, U., Jimenez, J. L., Artaxo, P., and Martin, S. T.: Submicron particle mass concentrations and sources in the Amazonian 
wet season (AMAZE-08), Atmos. Chem. Phys., 15, 3687-3701, https://doi.org/10.5194/acp-15-3687-2015, 2015.

Chen, Y., Shah, N., Huggins, F. E., and Huffman, G. P.: Characterization of ambient airborne particles by energy-filtered transmission electron microscopy, Aerosol Sci. Tech., 39, 509-518, https://doi.org/10.1080/027868291001402, 2005.

Chen, Y., Shah, N., Huggins, F. E., and Huffman, G. P.: Microanalysis of ambient particles from Lexington, KY, by electron microscopy, Atmos. Environ., 40, 651-663, https://doi.org/10.1016/j.atmosenv.2005.09.036, 2006.

China, S., Wang, B., Weis, J., Rizzo, L., Brito, J., Cirino, G. G., Kovarik, L., Artaxo, P., Gilles, M. K., and Laskin, A.: Rupturing of Biological Spores As a Source of Secondary Particles in Amazonia, Environ. Sci. Technol., 50, 12179-12186, https://doi.org/10.1021/acs.est.6b02896, 2016.

de Sá, S. S., Palm, B. B., Campuzano-Jost, P., Day, D. A., Hu, W., Isaacman-VanWertz, G., Yee, L. D., Brito, J., Carbone, S., Ribeiro, I. O., Cirino, G. G., Liu, Y. J., Thalman, R., Sedlacek, A., Funk, A., Schumacher, C., Shilling, J. E., Schneider, J., Artaxo, P., Goldstein, A. H., Souza, R. A. F., Wang, J., McKinney, K. A., Barbosa, H., Alexander, M. L., Jimenez, J. L., and Martin, S. T.: Urban influence on the concentration and composition of submicron particulate matter in central Amazonia, Atmos. Chem. Phys., 18, 12185-12206, https://doi.org/10.5194/acp-18-121852018, 2018.

Eom, H.-J., Gupta, D., Li, X., Jung, H.-J., Kim, H., and Ro, C.-U.: Influence of Collecting Substrates on the Characterization of Hygroscopic Properties of Inorganic Aerosol Particles, Anal. Chem., 86, 2648-2656, https://doi.org/10.1021/ac4042075, 2014.

Eom, H.-J., Gupta, D., Cho, H.-R., Hwang, H. J., Hur, S. D., Gim, Y., and Ro, C.-U.: Single-particle investigation of summertime and wintertime Antarctic sea spray aerosols using low$\mathrm{Z}$ particle EPMA, Raman microspectrometry, and ATR-FTIR imaging techniques, Atmos. Chem. Phys., 16, 13823-13836, https://doi.org/10.5194/acp-16-13823-2016, 2016.

Fan, J., Rosenfeld, D., Zhang, Y., Giangran, S. E., Li, Z., Machado, L. A. T., Martin, S. T., Yang, Y., Wang, J., Artaxo, P., Barbosa, H. M. J., Braga, R. C., Comstock, J. M., Feng, Z., Gao, W., Gomes, H. B., Mei, F., Pöhlker, C., Pöhlker, M. L., Pöschl, U., and de Souza, R. A. F.: Substantial convection and precipitation enhancements by ultrafine aerosol particles, Science, 359, 411418, 2018.

Fraund, M., Pham, D. Q., Bonanno, D., Harder, T. H., Wang, B., Brito, J., de Sá, S. S., Carbone, S., China, S., Artaxo, P., Martin, S. T., Pöhlker, C., Andreae, M. O., Laskin, A., Gilles, M., K., and Moffet, R. C.: Elemental Mixing State of Aerosol Particles Collected in Central Amazonia during GoAmazon2014/15, Atmosphere, 8, 173, https://doi.org/10.3390/atmos8090173, 2017.

Fung, K. H. and Tang, I. N.: Raman spectra of singly suspended supersaturated ammonium bisulfate droplets, Chem. Phys. Lett., 147, 509-513, https://doi.org/10.1016/0009-2614(88)85017-6, 1988.

Fuzzi, S., Decesari, S., Facchini, M. C., Cavalli, F., Emblico, L., Mircea, M., Andreae, M. O., Trebs, I., Hoffer, A., Guyon, P., Artaxo, P., Rizzo, L. V., Lara, L. L., Pauliquevis, T., Maenhaut, W., Raes, N., Chi, X., Mayol-Bracero, O. L., Soto-García, L. L., Claeys, M., Kourtchev, I., Rissler, J., Swietlicki, E., Tagliavini, E., Schkolnik, G., Falkovich, A. H., Rudich, Y., Fisch, G., and
Gatti, L. V.: Overview of the inorganic and organic composition of size-segregated aerosol in Rondonia, Brazil, from the biomassburning period to the onset of the wet season, J. Geophys. Res., 112, D01201, https://doi.org/10.1029/2005JD006741, 2007.

Geng, H., Jung, H.-J., Park, Y., Hwang, H., Kim, H., Kim, Y. J., Sunwoo, Y., and Ro, C.-U.: Morphological and chemical composition characteristics of summertime atmospheric particles collected at Tokchok Island, Korea, Atmos. Environ. 43, 33643373, https://doi.org/10.1016/j.atmosenv.2009.03.034, 2009.

Geng, H., Kang, S., Choel, M., Kim, H., and Ro, C.-U.: Characterization of individual submicrometer aerosol particles collected in Incheon, Korea, by quantitative transmission electron microscopy energy-dispersive X-ray spectrometry, J. Geophys. Res., 115, D15306, https://doi.org/10.1029/2009JD013486, 2010.

Geng, H., Ryu, J., Maskey, S., Jung, H.-J., and Ro, C.-U.: Characterisation of individual aerosol particles collected during a haze episode in Incheon, Korea using the quantitative ED-EPMA technique, Atmos. Chem. Phys. 11, 1327-1337, https://doi.org/10.5194/acp-11-1327-2011, 2011.

Geng, H., Hwang, H., Liu, X., Dong, S., and Ro, C.-U.: Investigation of aged aerosols in size resolved Asian dust storm particles transported from Beijing, China, to Incheon, Korea, using low-Z particle EPMA, Atmos. Chem. Phys., 14, 3307-3323, https://doi.org/10.5194/acp-14-3307-2014, 2014.

Geng, H., Jin, C.-S., Zhang, D.-P., Wang, S.-R., Xu, X.-T., Wang, X.-R., Zhang, Y., Wu, L., and Ro, C.-U.: Characterization of size-resolved urban haze particles collected in summer and winter at Taiyuan City, China using quantitative electron probe X-ray microanalysis, Atmos. Res., 190, 29-42, https://doi.org/10.1016/j.atmosres.2017.02.005, 2017.

Gilardoni, S., Vignati, E., Marmer, E., Cavalli, F., Belis, C., Gianelle, V., Loureiro, A., and Artaxo, P.: Sources of carbonaceous aerosol in the Amazon basin, Atmos. Chem. Phys., 11, 27472764, https://doi.org/10.5194/acp-11-2747-2011, 2011.

Goldstein, J., Newbury, D., Joy, D., Lyman, C., Echlin, P., Lifshin, E., Sawyer, L., and Michael, J.: Scanning Electron Microscopy and X-ray Microanalysis, 3rd Edn., Kluwer Academic/Plenum Publishers, New York, 2003.

Gregory, G. L., Harriss, R. C., Talbot, R. W., Rasmussen, R. A., Garstang, M., Andreae, M. O., Hinton, R. R., Browell, E. V., Beck, S. M., Sebacher, D. I., Khalil, M. A. K., Ferek, R. J., and Harriss, S. V.: Air chemistry over the tropical forest of Guyana, J. Geophys. Res., 91, 8603-8612, 1986.

Haga, D. I., Burrows, S. M., Iannone, R., Wheeler, M. J., Mason, R. H., Chen, J., Polishchuk, E. A., Pöschl, U., and Bertram, A. K.: Ice nucleation by fungal spores from the classes Agaricomycetes, Ustilaginomycetes, and Eurotiomycetes, and the effect on the atmospheric transport of these spores, Atmos. Chem. Phys., 14, 8611-8630, https://doi.org/10.5194/acp-14-8611-2014, 2014.

Hallquist, M., Wenger, J. C., Baltensperger, U., Rudich, Y., Simpson, D., Claeys, M., Dommen, J., Donahue, N. M., George, C., Goldstein, A. H., Hamilton, J. F., Herrmann, H., Hoffmann, T., Iinuma, Y., Jang, M., Jenkin, M. E., Jimenez, J. L., KiendlerScharr, A., Maenhaut, W., McFiggans, G., Mentel, T. F., Monod, A., Prévôt, A. S. H., Seinfeld, J. H., Surratt, J. D., Szmigielski, R., and Wildt, J.: The formation, properties and impact of secondary organic aerosol: current and emerging issues, Atmos. 
Chem. Phys., 9, 5155-5236, https://doi.org/10.5194/acp-9-51552009, 2009.

Hansen, K., Pryor, S. C., Boegh, E., Hornsby, K. E., Jensen, B., and Sørensen, L. L.: Background concentrations and fluxes of atmospheric ammonia over a deciduous forest, Agr. Forest Meteorol., 214-215, 380-392, https://doi.org/10.1016/j.agrformet.2015.09.004, 2015.

Hansen, K., Personne, E., Skjøth, C. A., Loubet, B., Ibrom, A., Jensen, R., Sørensen, L. L., and Boegh, E.: Investigating sources of measured forest-atmosphere ammonia fluxes using two-layer bi-directional modelling, Agr. Forest Meteorol., 237-238, 80-94, https://doi.org/10.1016/j.agrformet.2017.02.008, 2017.

Huang, P. F. and Turpin, B.: Reduction of sampling and analytical errors for electron microscopic analysis of atmospheric aerosols, Atmos. Environ., 30, 4137-4148, 1996.

IBGE: Estimates of the resident population in Brazil and Federative Units, Brazilian Institute of Geography and Statistics, Castelo, Rio de Janeiro, Brazil, 2017.

Jardine, K., Yañez-Serrano, A. M., Williams, J., Kunert, N., Jardine, A., Taylor, T., Abrell, L., Artaxo, P., Guenther, A., Hewitt, C. N., House, E., Florentino, A. P., Manzi, A., Higuchi, N., Kesselmeir, J., Behrendt, T., Veres, P. R., Derstroff, B., Fuentes, J. D., Martin, S. T., Andreae, M. O.: Dimethyl sulfide in the Amazon rain forest, Global Biogeochem. Cy., 29, 19-32, https://doi.org/10.1002/2014GB004969, 2015.

Jimenez, J. L., Canagaratna, M. R., Donahue, N. M., Prevot, A. S. H., Zhang, Q., Kroll, J. H., DeCarlo, P. F., Allan, J. D., Coe, H., Ng, N. L., Aiken, A. C., Docherty, K. S., Ulbrich, I. M., Grieshop, A. P., Robinson, A. L., Duplissy, J., Smith, J. D., Wilson, K. R., Lanz, V. A., Hueglin, C., Sun, Y. L., Tian, J., Laaksonen, A., Raatikainen, T., Rautiainen, J., Vaattovaara, P., Ehn, M., Kulmala, M., Tomlinson, J. M., Collins, D. R., Cubison, M. J., Dunlea, E. J., Huffman, J. A., Onasch, T. B., Alfarra, M. R., Williams, P. I., Bower, K., Kondo, Y., Schneider, J., Drewnick, F., Borrmann, S., Weimer, S., Demerjian, K., Salcedo, D., Cottrell, L., Griffin, R., Takami, A., Miyoshi, T., Hatakeyama, S., Shimono, A., Sun, J. Y., Zhang, Y. M., Dzepina, K., Kimmel, J. R., Sueper, D., Jayne, J. T., Herndon, S. C., Trimborn, A. M., Williams, L. R., Wood, E. C., Middlebrook, A. M., Kolb, C. E., Baltensperger, U., and Worsnop, D. R.: Evolution of organic aerosols in the atmosphere, Science, 326, 1525-1529, https://doi.org/10.1126/science.1180353, 2009.

Jordan, C., Caskey, W., Escalante, G., Herrera, R., Montagnini, F., Todd, R., and Uhl, C.: The nitrogen cycle in a 'Terra Firme' rainforest on oxisol in the Amazon territory of Venezuela, Plant Soil, 67, 325-332, https://doi.org/10.1007/BF02182779, 1982.

Kellerhals, T., Brütsch, S., Sigl, M., Knüsel, S., Gäggeler, H. W., and Schwikowski, M.: Ammonium concentration in ice cores: A new proxy for regional temperature reconstruction?, J. Geophys. Res., 115, D16123, https://doi.org/10.1029/2009JD012603, 2010.

Kim, J. and Rees, D. C.: Nitrogenase and biological nitrogen fixation, Biochemistry, 33, 389-397, 1994.

Krejci, R., Ström, J., de Reus, M., and Sahle, W.: Single particle analysis of the accumulation mode aerosol over the northeast Amazonian tropical rain forest, Surinam, South America, Atmos. Chem. Phys., 5, 3331-3344, https://doi.org/10.5194/acp-5-33312005, 2005.
Laskin, A., Gaspar, D. J., Wang, W., Hunt, S. W., Cowin, J. P., Colson, S. D., and Finlayson- Pitts, B. J.: Reactions at Interfaces as a Source of Sulfate Formation in Sea-Salt Particles, Science, 301, 340-344, https://doi.org/10.1126/science.1085374, 2003.

Laskin, A., Laskin, J., and Nizkorodov, S. A.: Chemistry of Atmospheric Brown Carbon, Chem. Rev., 115, 4335-4382, https://doi.org/10.1021/cr5006167, 2015.

Li, W., Shao, L., Zhang, D., Ro, C.-U., Hu, M., Bi, X., Geng, H., Matsuki, A., Niu, H., and Chen, J.: A review of single aerosol particle studies in the atmosphere of East Asia: morphology, mixing state, source, and heterogeneous reactions, J. Clean. Prod., 112, 1330-1349, https://doi.org/10.1016/j.jclepro.2015.04.050, 2016.

Lin, G., Sillman, S., Penner, J. E., and Ito, A.: Global modeling of SOA: the use of different mechanisms for aqueous-phase formation, Atmos. Chem. Phys., 14, 5451-5475, https://doi.org/10.5194/acp-14-5451-2014, 2014.

Ling, T. Y. and Chan, C. K.: Formation and transformation of metastable double salts from the crystallization of mixed ammonium nitrate and ammonium sulfate particles, Environ. Sci. Technol., 41, 8077-8083, https://doi.org/10.1021/es071419t, 2007.

Mabrouk, K. B., Kauffmann, T. H., Aroui, H., and Fontana, M. D.: Raman study of cation effect on sulfate vibration modes in solid state and in aqueous solutions, J. Raman Spectrosc., 44, 16031608, https://doi.org/10.1002/jrs.4374, 2013.

Mace, K. A., Artaxo, P., and Duce, R. A.: Water-soluble organic nitrogen in Amazon Basin aerosols during the dry (biomass burning) and wet seasons, J. Geophys. Res., 108, 4512, https://doi.org/10.1029/2003JD003557, 2003.

Martin, S. T., Andreae, M. O., Artaxo, P., Baumgardner, D., Chen, Q., Goldstein, A. H., Guenther, A., Heald, C. L., Mayol-Bracero, O. L., McMurry, P. H., Pauliquevis, T., Pöschl, U., Prather, K. A., Roberts, G. C., Saleska, S. R., Dias, M. A. S., Spracklen, D. V., Swietlicki, E., and Trebs, I.: Sources and properties of Amazonian aerosol particles, Rev. Geophys., 48, RG2002, https://doi.org/10.1029/2008rg000280, 2010a.

Martin, S. T., Andreae, M. O., Althausen, D., Artaxo, P., Baars, H., Borrmann, S., Chen, Q., Farmer, D. K., Guenther, A., Gunthe, S. S., Jimenez, J. L., Karl, T., Longo, K., Manzi, A., Müller, T., Pauliquevis, T., Petters, M. D., Prenni, A. J., Pöschl, U., Rizzo, L. V., Schneider, J., Smith, J. N., Swietlicki, E., Tota, J., Wang, J., Wiedensohler, A., and Zorn, S. R.: An overview of the Amazonian Aerosol Characterization Experiment 2008 (AMAZE-08), Atmos. Chem. Phys., 10, 1141511438, https://doi.org/10.5194/acp-10-11415-2010, 2010b.

Martin, S. T., Artaxo, P., Machado, L. A. T., Manzi, A. O., Souza, R. A. F., Schumacher, C., Wang, J., Andreae, M. O., Barbosa, H. M. J., Fan, J., Fisch, G., Goldstein, A. H., Guenther, A., Jimenez, J. L., Pöschl, U., Silva Dias, M. A., Smith, J. N., and Wendisch, M.: Introduction: Observations and Modeling of the Green Ocean Amazon (GoAmazon2014/5), Atmos. Chem. Phys., 16, 47854797, https://doi.org/10.5194/acp-16-4785-2016, 2016.

Maskey, S., Choël, M., Kang, S., Hwang, H., Kim, H., and Ro, C.U.: The influence of collecting substrates on the single-particle characterization of real atmospheric aerosols, Anal. Chim. Acta, 658, 120-127, https://doi.org/10.1016/j.aca.2009.11.006, 2010.

Medeiros, A. S. S., Calderaro, G., Guimarães, P. C., Magalhaes, M. R., Morais, M. V. B., Rafee, S. A. A., Ribeiro, I. O., Andreoli, R. V., Martins, J. A., Martins, L. D., Martin, S. T., and Souza, 
R. A. F.: Power plant fuel switching and air quality in a tropical, forested environment, Atmos. Chem. Phys., 17, 8987-8998, https://doi.org/10.5194/acp-17-8987-2017, 2017.

Millstein, D. E., Harley, R. A., and Hering, S. V.: Weekly cycles in fine particulate nitrate, Atmos. Environ. 42, 632-641, https://doi.org/10.1016/j.atmosenv.2007.10.010, 2008.

Möhler, O., Benz, S., Saathoff, H., Schnaiter, M., Wagner, R., Schneider, J., Walter, S., Ebert, V., and Wagner, S.: The effect of organic coating on the heterogeneous ice nucleation efficiency of mineral dust aerosols, Environ. Res. Lett., 3, 025007 , https://doi.org/10.1088/1748-9326/3/2/025007, 2008.

Moran-Zuloaga, D., Ditas, F., Walter, D., Saturno, J., Brito, J., Carbone, S., Chi, X., de Angelis, I. H., Baars, H., Godoi, R. H. M., Heese, B., Holanda, B. A., Lavrič, J.V., Martin, S. T., Ming, J., Pöhlker, M. L., Ruckteschler, N., Su, H., Wang, Y., Wang, Q., Wang, Z., Weber, B., Wolff, S., Artaxo, P., Pöschl, U., Andreae, M. O., and Pöhlker, C.: Long-term study on coarse mode aerosols in the Amazon rain forest with the frequent intrusion of Saharan dust plumes, Atmos. Chem. Phys, 18, 10055-10088, https://doi.org/10.5194/acp-18-10055-2018, 2018.

Neill, C., Piccolo, M. C., Melillo, J. M., Steudler, P. A., Cerri, C. C.: Nitrogen dynamics in Amazon forest and pasture soils measured by ${ }^{15} \mathrm{~N}$ pool dilution, Soil Biol. Biochem., 31, 567-572, 1999.

Palm, B. B., de Sá, S. S., Day, D.A., Campuzano-Jost, P., Hu, W., Seco, R., Sjostedt, S. J., Park, J.-H., Guenther, A. B., Kim, S., Brito, J., Wurm, F., Artaxo, P., Thalman, R., Wang, J., Yee, L. D., Wernis, R., Isaacman-VanWertz, G., Goldstein, A. H., Liu, Y., Springston, S. R., Souza, R., Newburn, M. K., Alexander, M. L., Martin, S. T., and Jimenez, J. L.: Secondary organic aerosol formation from ambient air in an oxidation flow reactor in central Amazonia, Atmos. Chem. Phys., 18, 467-493, https://doi.org/10.5194/acp-18-467-2018, 2018.

Pöhlker, C., Wiedemann, K. T., Sinha, B., Shiraiwa, M., Gunthe, S. S., Smith, M., Su, H., Artaxo, P., Chen, Q., Cheng, Y. F., Elbert, W., Gilles, M. K., Kilcoyne, A. L. D., Moffet, R. C., Weigand, M., Martin, S. T., Poeschl, U., and Andreae, M. O.: Biogenic potassium salt particles as seeds for secondary organic aerosol in the Amazon, Science, 337, 1075-1078, https://doi.org/10.1126/science.1223264, 2012.

Pöhlker, M. L., Ditas, F., Saturno, J., Klimach, T., Hrabě de Angelis, I., Araùjo, A. C., Brito, J., Carbone, S., Cheng, Y., Chi, X., Ditz, R., Gunthe, S. S., Holanda, B. A., Kandler, K., Kesselmeier, J., Könemann, T., Krüger, O. O., Lavrič, J. V., Martin, S. T., Mikhailov, E., Moran-Zuloaga, D., Rizzo, L. V., Rose, D., Su, H., Thalman, R., Walter, D., Wang, J., Wolff, S., Barbosa, H. M. J., Artaxo, P., Andreae, M. O., Pöschl, U., and Pöhlker, C.: Long-term observations of cloud condensation nuclei over the Amazon rain forest - Part 2: Variability and characteristics of biomass burning, long-range transport, and pristine rain forest aerosols, Atmos. Chem. Phys., 18, 10289-10331, https://doi.org/10.5194/acp-18-10289-2018, 2018.

Pöschl, U., Martin, S. T., Sinha, B., Chen, Q., Gunthe, S. S., Huffman, J. A., Borrmann, S., Farmer, D. K., Garland, R. M., Helas, G., Jimenez, J. L., King, S. M., Manzi, A., Mikhailov, E., Pauliquevis, T., Petters, M. D., Prenni, A. J., Roldin, P., Rose, D., Schneider, J., Su, H., Zorn, S. R., Artaxo, P., and Andreae, M. O.: Rainforest Aerosols as Biogenic Nuclei of Clouds and Precipitation in the Amazon, Science, 329, 15131516, https://doi.org/10.1126/science.1191056, 2010.
Pósfai, M., Xu, H., Anderson, and Buseck, P. R.: Wet and dry sizes of atmospheric aerosol particles: An AFM-TEM study, Geophys. Res. Lett., 25, 1907-1910, https://doi.org/10.1029/98GL01416, 1998.

Pósfai, M., Anderson, J. R., Buseck, P. R., and Sievering, H.: Soot and sulfate aerosol particles in the remote marine troposphere, J. Geophys. Res., 104, 21685-21693, https://doi.org/10.1029/1999JD900208, 1999.

Pósfai, M., Simonics, R., Li, J., Hobbs, P. V., and Buseck, P. R.: Individual aerosol particles from biomass burning in southern Africa: 1. Compositions and size distributions of carbonaceous particles, J. Geophys. Res., 108, 8483, https://doi.org/10.1029/2002JD002291, 2003.

Pósfai, M., Gelencser, A., Simonics, R., Arato, K., Li, J., Hobbs, P. V., and Buseck, P. R.: Atmospheric tarballs: Particles from biomass and biofuel burning, J. Geophys. Res., 109, D06213, https://doi.org/10.1029/2003JD004169, 2004.

Prieto-Taboada, N., Gomez-Laserna, O., Martinez-Arkarazo, I., Olazabal, M. A., and Madariaga, J. M.: Raman Spectra of the Different Phases in the $\mathrm{CaSO}_{4}-\mathrm{H}_{2} \mathrm{O}$ System, Anal. Chem., 86, 10131-10137, https://doi.org/10.1021/ac501932f, 2014.

Qiao, T., Zhao,M., Xiu, G., and Yu, J.: Simultaneous monitoring and compositions analysis of $\mathrm{PM}_{1}$ and $\mathrm{PM}_{2.5}$ in Shanghai: implications for characterization of haze pollution and source apportionment, Sci. Total Environ., 557-558, 386-394, https://doi.org/10.1016/j.scitotenv.2016.03.095, 2016.

Rizzolo, J. A., Barbosa, C. G. G., Borillo, G. C., Godoi, A. F. L., Souza, R. A. F., Andreoli, R. V., Manzi, A. O., Sá, M. O., Alves, E. G., Pöhlker, C., Angelis, I. H., Ditas, F., Saturno, J., MoranZuloaga, D., Rizzo, L. V., Rosário, N. E., Pauliquevis, T., Santos, R. M. N., Yamamoto, C. I., Andreae, M. O., Artaxo, P., Taylor, P. E., and Godoi, R. H. M.: Soluble iron nutrients in Saharan dust over the central Amazon rainforest, Atmos. Chem. Phys., 17, 2673-2687, https://doi.org/10.5194/acp-17-2673-2017, 2017.

Saturno, J., Ditas, F., Penning de Vries, M., Holanda, B. A., Pöhlker, M. L., Carbone, S., Walter, D., Bobrowski, N., Brito, J., Chi, X., Gutmann, A., Hrabe de Angelis, I., Machado, L. A. T., Moran-Zuloaga, D., Rüdiger, J., Schneider, J., Schulz, C., Wang, Q., Wendisch, M., Artaxo, P., Wagner, T., Pöschl, U., Andreae, M. O., and Pöhlker, C.: African volcanic emissions influencing atmospheric aerosols over the Amazon rain forest, Atmos. Chem. Phys., 18, 10391-10405, https://doi.org/10.5194/acp-18-103912018, 2018.

Sobanska, S., Hwang, H., Choël, M., Jung, H., Eom, H., Kim, H., Barbillat, J., and Ro, C.-U.: Investigation of the chemical mixing state of individual Asian Dust particles by the combined use of Electron Probe X-ray Microanalysis and Raman Microspectrometry, Anal. Chem., 84, 3145-3154, https://doi.org/10.1021/ac2029584, 2012.

Su, L., Yuan, Z., Fung, J. C. H., and Lau, A. K. H.: A comparison of HYSPLIT backward trajectories generated from two GDAS datasets, Sci. Total Environ., 506-507, 527-537, https://doi.org/10.1016/j.scitotenv.2014.11.072, 2015.

Sullivan, R. C., Guazzotti, S. A., Sodeman, D. A., and Prather, K. A.: Direct observations of the atmospheric processing of Asian mineral dust, Atmos. Chem. Phys., 7, 1213-1236, https://doi.org/10.5194/acp-7-1213-2007, 2007.

Sutton, M. A., Nemitz, E., Milford, C., Campbell, C., Erisman, J. W., Hensen, A., Cellier, P., David, M., Loubet, B., Personne, 
E., Schjoerring, J. K., Mattsson, M., Dorsey, J. R., Gallagher5, L. Horvath, M. W., Weidinger, T., Meszaros, R., Dämmgen, U., Neftel, A., Herrmann, B., Lehman, B. E., Flechard, C., and Burkhardt, J.: Dynamics of ammonia exchange with cut grassland: synthesis of results and conclusions of the GRAMINAE integrated experiment, Biogeosciences, 6, 2907-2934, https://doi.org/10.5194/bg-6-2907-2009, 2009.

Sutton, M. A., Reis, S., Riddick, S. N., Dragosits, U., Nemitz, E., Theobald, M. R., Tang,Y. S., Braban, C. F., Vieno, M., Dore, A. J., Mitchell, R. F., Wanless, S., Daunt, F., Fowler, D., Blackall, T. D., Milford, C., Flechard, C. R., Loubet, B., Massad, R., Cellier, P., Personne, E., Coheur, P. F., Clarisse, L., Van Damme, M., Ngadi, Y., Clerbaux, C., Skjøth, C. A., Geels, C., Hertel, O., Wichink Kruit, R. J., Pinder, R. W., Bash, J. O., Walker, J. T., Simpson, D., Horvath, L., Misselbrook, T. H., Bleeker, A., Dentener, F., and de Vries, W.: Towards a climate-dependent paradigm of ammonia emission and deposition, Philos. T. Roy. Soc. Lond. B, 368, 20130166, https://doi.org/10.1098/rstb.2013.0166, 2013.

Swap, R., Garstang, M., Greco, S., Talbot, R., and Kållberg, P.: Saharan dust in the Amazon Basin, Tellus B, 44, 133-149, 1992.

Talbot, R. W., Andreae, M. O., Berresheim, H., Artaxo, P., Garstang, M., Harriss, R. C., Beecher, K. M., and Li, S. M.: Aerosol chemistry during the wet season in Central Amazonia: The influence of long-range transport, J. Geophys. Res., 95, 16955-16969, 1990.

ten Brink, H. M.: Reactive uptake of $\mathrm{HNO}_{3}$ and $\mathrm{H}_{2} \mathrm{SO}_{4}$ in sea-salt $(\mathrm{NaCl})$ particles, J. Aerosol Sci., 29, 57-64, https://doi.org/10.1016/s0021-8502(97)00460-6, 1998.

Tobo, Y., Prenni, A. J., DeMott, P. J., Huffman, J. A., McCluskey, C. S., Tian, G., Pöhlker, C., Pöschl, U., and Kreidenweis, S. M.: Biological aerosol particles as a key determinant of ice nuclei populations in a forest ecosystem, J. Geophys. Res., 118, 1010010110, https://doi.org/10.1002/jgrd.50801, 2013.
Vekemans, B., Janssens, K., Vincze, L., Adams, F., and Van Espen, P.: Analysis of X-ray spectra by iterative least squares (AXIL): New developments, X-Ray Spectrom., 23, 278-285, 1994.

Wang, A., Freeman, J. J., Jolliff, B. L., and Chou, I.-M.: Sulfates on Mars: A systematic Raman spectroscopic study of hydration states of magnesium sulfates, Geochim. Cosmochim. Ac., 70, 6118-6135, https://doi.org/10.1016/j.gca.2006.05.022, 2006.

Wang, B., Harder, T. H., Kelly, S. T., Piens, D. S., China, S., Kovarik, L., Keiluweit, M., Arey, B. W., Gilles, M. K., and Laskin, A.: Airborne soil organic particles generated by precipitation, Nat. Geosci., 9, 433-437, https://doi.org/10.1038/ngeo2705, 2016.

Worobiec, A., de Hoog, J., Osan, J., Szaloki, I., Ro, C.-U., and Van Grieken, R.: Thermal stability of beam sensitive atmospheric aerosol particles in electron probe microanalysis at liquid nitrogen temperature, Spectrochim. Acta B, 58, 479-496, 2003.

Wright, S. J.: Phenological responses to seasonality in tropical forest plants, 440-460, in Tropical Forest Plant Ecophysiology, Mulkey S. S., Chazdon, R. L., and Smith A. P. (Eds), Springer, 1996.

Yeung, M. C. and Chan, C. K.: Water content and phase transitions in particles of inorganic and organic species and their mixtures using Micro-Raman Spectroscopy, Aerosol Sci. Tech., 4, 269280, https://doi.org/10.1080/02786820903583786, 2010.

Zhang, R., Khalizov, A. F., Khalizov, J., Zhang, D., Xue, H., and McMurry, P. H.: Variability in morphology, hygroscopicity, and optical properties of soot aerosols during atmospheric processing, P. Natl. Acad. Sci. USA, 105, 10291-10296, https://doi.org/10.1073/pnas.0804860105, 2008. 